\title{
Air quality modeling with WRF-Chem v3.5 in East Asia: sensitivity to emissions and evaluation of simulated air quality
}

\author{
Min Zhong ${ }^{1}$, Eri Saikawa ${ }^{1,2}$, Yang Liu ${ }^{2}$, Vaishali Naik ${ }^{3}$, Larry W. Horowitz ${ }^{3}$, Masayuki Takigawa ${ }^{4}$, Yu Zhao ${ }^{5}$, \\ Neng-Huei Lin ${ }^{6}$, and Elizabeth A. Stone \\ ${ }^{1}$ Department of Environmental Sciences, Emory University, Atlanta, GA, USA \\ ${ }^{2}$ Department of Environmental Health, Rollins School of Public Health, Emory University, Atlanta, GA, USA \\ ${ }^{3}$ NOAA Geophysical Fluid Dynamics Laboratory, Princeton, NJ, USA \\ ${ }^{4}$ Japan Agency for Marine-Earth Science and Technology, Yokohama, Japan \\ ${ }^{5}$ Nanjing University, Nanjing, China \\ ${ }^{6}$ Department of Atmospheric Sciences, National Central University, Chuang-Li, Taiwan \\ ${ }^{7}$ Department of Chemistry, University of Iowa, Iowa City, IA, USA
}

Correspondence to: Min Zhong (min.zhong@emory.edu) and Eri Saikawa (eri.saikawa@emory.edu)

Received: 1 September 2015 - Published in Geosci. Model Dev. Discuss.: 29 October 2015

Revised: 8 February 2016 - Accepted: 7 March 2016 - Published: 1 April 2016

\begin{abstract}
We conducted simulations using the Weather Research and Forecasting model coupled with Chemistry (WRF-Chem) version 3.5 to study air quality in East Asia at a spatial resolution of $20 \mathrm{~km} \times 20 \mathrm{~km}$. We find large discrepancies between two existing emissions inventories: the Regional Emission Inventory in ASia version 2 (REAS) and the Emissions Database for Global Atmospheric Research version 4.2 (EDGAR) at the provincial level in China, with maximum differences of up to $500 \%$ for CO emissions, $190 \%$ for $\mathrm{NO}$, and $160 \%$ for primary $\mathrm{PM}_{10}$. Such discrepancies in the magnitude and the spatial distribution of emissions for various species lead to a 40-70\% difference in surface $\mathrm{PM}_{10}$ concentrations, $16-20 \%$ in surface $\mathrm{O}_{3}$ mixing ratios, and over $100 \%$ in $\mathrm{SO}_{2}$ and $\mathrm{NO}_{2}$ mixing ratios in the polluted areas of China. WRF-Chem is sensitive to emissions, with the REAS-based simulation reproducing observed concentrations and mixing ratios better than the EDGAR-based simulation for July 2007. We conduct additional model simulations using REAS emissions for January, April, July, and October of 2007 and evaluate simulations with available ground-level observations. The model results illustrate clear regional variations in the seasonal cycle of surface $\mathrm{PM}_{10}$ and $\mathrm{O}_{3}$ over East Asia. The model meets the air quality model performance criteria for both $\mathrm{PM}_{10}$ (mean fractional bias, $\mathrm{MFB} \leqslant \pm 60 \%)$ and $\mathrm{O}_{3}(\mathrm{MFB} \leqslant \pm 15 \%)$ at most of the observation sites, although the model underestimates $\mathrm{PM}_{10}$
\end{abstract}

over northeastern China in January. The model predicts the observed $\mathrm{SO}_{2}$ well at sites in Japan, while it tends to overestimate $\mathrm{SO}_{2}$ in China in July and October. The model underestimates observed $\mathrm{NO}_{2}$ in all 4 months. Our study highlights the importance of constraining emissions at the provincial level for regional air quality modeling over East Asia. Our results suggest that future work should focus on the improvement of provincial-level emissions especially estimating primary $\mathrm{PM}, \mathrm{SO}_{2}$, and $\mathrm{NO}_{x}$.

\section{Introduction}

Many Asian countries have faced deteriorating air quality since the late 1990s and early 2000s due to rapid economic development and population growth. According to the latest World Health Organization (WHO) ambient air pollution database (WHO, 2014), air quality in China and India was ranked 14th and 9th, respectively, out of the 91 most polluted countries. Since these countries have the largest population in the world, exposure to air pollutants poses health risks to billions of residents. For example, Chen et al. (2013) reported that outdoor air pollution in China alone caused approximately half a million premature deaths every year. A similar number of premature deaths was estimated in India in 2010 (HEI, 2013). Air pollution not only impacts human 
health, but also has important potential consequences for natural ecosystems, crop yields, visibility, and radiative forcing (Seinfeld and Pandis, 2006). In order to mitigate these negative consequences, it is essential to have a better understanding of air pollutant emissions sources and magnitudes, as well as atmospheric transport and chemical composition over the region.

Several modeling studies have applied the Weather Research and Forecasting model coupled with Chemistry (WRF-Chem) (Grell et al., 2005) to study air quality in Asia. Saikawa et al. (2011) analyzed the impact of China's vehicle emissions on air quality both within China and across East Asia. They found that stricter regulation of the road transport sector in China would reduce surface concentrations of fine particulate matter with an aerodynamic diameter of $2.5 \mu \mathrm{m}$ or less $\left(\mathrm{PM}_{2.5}\right)$ and tropospheric ozone $\left(\mathrm{O}_{3}\right)$ mixing ratios in the region. Kumar et al. (2012) examined ground-level measurements and satellite observations in South Asia and reported that WRF-Chem could simulate $\mathrm{O}_{3}$ and $\mathrm{CO}$ well, but large discrepancies were found for $\mathrm{NO}_{2}$ due to uncertainties in emissions from biomass burning and anthropogenic $\mathrm{NO}_{x}$ estimates. Wang et al. (2010) conducted sensitivity analyses of $\mathrm{O}_{3}, \mathrm{NO}_{x}$, and sulfur dioxide $\left(\mathrm{SO}_{2}\right)$ mixing ratios to temporal and vertical emissions; their results showed that air quality in East Asia was impacted by the diurnal and vertical distribution of anthropogenic emissions. Studies that have conducted WRF-Chem modeling for $\mathrm{PM}_{2.5}$ and $\mathrm{PM}_{10}$ have found that these surface concentrations were usually underestimated. For example, Saikawa et al. (2011) reported that modeled 4-month average $\mathrm{PM}_{2.5}$ concentrations at $\mathrm{Oki}$ and Rishiri in Japan had a mean normalized bias (MNB) of $-34 \%$ compared to observations. Gao et al. (2014) compared simulated and measured $\mathrm{PM}_{10}$ concentrations at six sites in Japan and found that the model underestimated the annual average $\mathrm{PM}_{10}$ at all sites except one.

One of the possible reasons that models underestimate particulate matter (PM) concentrations is the uncertainty in emissions. Several emissions inventories for Asia have been developed by different groups, each with different purposes and characteristics (Kurokawa et al., 2013; JRC and PBL, 2010; Streets et al., 2003; Klimont et al., 2011). Comparison of the emissions inventories has revealed large differences in these emissions estimates. Kurokawa et al. (2013) compared different emissions inventories for several provinces in China and found that the difference in primary organic carbon emissions can be as high as $140 \%$. The possible causes of such discrepancies among emissions inventories are differences in estimates of (1) activity level, (2) level of technologies implemented, and (3) emissions factors. Since it is hard to measure emissions factors of each individual source at the scale of a province or a country, uncertainties arise when emissions factors from one place are applied to another. Activity data or emissions factors are often not available at the level of detail required for making insightful comparisons across emissions inventories.
While comparison of emissions inventories has revealed notable differences in the emissions estimates, few studies have addressed to what extent uncertainty in the emissions inventories really matters for the outcome of air quality modeling studies. Ma and van Aardenne (2004) compared simulated surface $\mathrm{O}_{3}$ mixing ratios over China using three different emissions inventories as model inputs, and found that surface $\mathrm{O}_{3}$ differed as much as 30-50\% among different model simulations. They also demonstrated that the differences in $\mathrm{NO}_{x}$ and non-methane volatile organic compounds (NMVOCs) among different inventories were dominant factors for the discrepancies in simulated $\mathrm{O}_{3}$ mixing ratios. Amnuaylojaroen et al. (2014), on the other hand, studied the effect of different anthropogenic emissions inventories on air quality over Southeast Asia and found only a small difference in simulated $\mathrm{O}_{3}$ (about $4.5 \%$ ) and $\mathrm{CO}$ (about $8 \%$ ) mixing ratios. However, these studies did not investigate the impact of emissions inventories on other pollutant species such as PM. Unlike the previous studies, which focused on uncertainties of simulated $\mathrm{O}_{3}, \mathrm{CO}$, and $\mathrm{NO}_{x}$, this study provides quantitative information on how emissions inventories impact PM and other pollutants including $\mathrm{SO}_{2}$.

The first objective of this paper is to study the sensitivity of regional air quality to emissions. We select two commonly used anthropogenic emissions inventories for comparison: the Regional Emission Inventory in ASia version 2 (REAS) (Kurokawa et al., 2013) and the Emissions Database for Global Atmospheric Research version 4.2 (EDGAR) (JRC and PBL, 2010). By comparing the 2-week model simulations using these two emissions inventories and observations from July 2007, we select the REAS inventory to perform air quality simulations over East Asia in different seasons. The second objective is to evaluate the simulated $\mathrm{PM}_{10}$ concentrations, as well as $\mathrm{O}_{3}, \mathrm{SO}_{2}$, and $\mathrm{NO}_{x}$ mixing ratios from four 1-month WRF-Chem runs against ground-level observations to build confidence in its ability to simulate future air quality over this region. WRF-Chem is an online-coupled meteorology and chemistry model, simulating meteorological quantities and air pollution concentrations simultaneously and allowing two-way interactions between meteorological and chemical constituents. In regions with high PM loading, meteorology-chemistry interaction significantly improves model performance in simulating air pollutant concentrations (Kong et al., 2015). So far, many of the WRFChem studies that focused on China conducted limited model evaluation due to the scarcity of observations in the region. This study compares the model simulations to observations from more than 70 sites in China to evaluate the model. There are some studies that have compared simulation results using a different chemical transport model (i.e., the Community Multi-scale Air Quality Model), but as far as we are aware, few studies have used as extensive a network of $\mathrm{PM}_{10}$ observations for WRF-Chem validation in this region as ours has. 
This paper is organized as follows. Section 2 explains the regional air quality model (WRF-Chem) configuration, emissions used for the model, observations used for validation, and data analysis methods. Section 3 analyzes the differences in emissions inventories and the sensitivity of simulated pollutant concentrations to the inventory used. Section 4 evaluates model performance by comparing observations with model simulations. Section 5 presents a summary of results and suggestions for future research.

\section{Model and observations description}

\subsection{Model description}

We use the fully coupled "online" regional chemical transport model WRF-Chem version 3.5 (Grell et al., 2005) in this study. The Regional Acid Deposition Model version 2 (RADM2) atmospheric chemical mechanism (Stockwell et al., 1990) is used for gas-phase chemistry. Aerosol chemistry is represented by the Model Aerosol Dynamics for Europe with the Secondary Organic Aerosol Model (MADE/SORGAM) (Schell et al., 2001; Ackermann et al., 1998) with some aqueous reactions. This aerosol mechanism is widely used in regional atmospheric chemistry models (Saikawa et al., 2011; Gao et al., 2014; Tuccella et al., 2012; Kumar et al., 2012). It predicts the mass of seven aerosol species (sulfate, ammonium, nitrate, sea salt, black carbon (BC), organic carbon (OC), and secondary organic aerosols), using three log-normal aerosol modes (Aitken, accumulation, and coarse). Aerosol dry deposition is simulated following the approach of Binkowski and Shankar (1995) and the wet removal approach follows Easter et al. (2004) and Chapman et al. (2009). Photolysis rates are obtained from the Fast-J photolysis scheme (Wild et al., 2000). We include the aerosol-radiative feedback in our simulation. The rapid radiative transfer model (RRTM) scheme (Mlawer et al., 1997) is used to represent both shortwave and longwave radiation. The horizontal winds, temperature, and moisture are nudged to 2007 meteorological fields at all vertical levels. The 2007 meteorological data are obtained from the National Center for Environmental Prediction (NCEP) Global Forecast System final gridded analysis data sets. We use the Lin et al. (1983) microphysics scheme and the Grell-3d ensemble cumulus parameterization (Grell and Dévényi, 2002).

The model domain, shown in Fig. 1, covers most of the East and South Asia region with $398 \times 298$ grid cells, using a $20 \mathrm{~km}$ spacing and a Lambert conformal map projection centered on China at $32^{\circ} \mathrm{N}, 100^{\circ} \mathrm{E}$. There are 31 vertical levels from the surface to $50 \mathrm{mb}$. The initial and lateral boundary conditions are taken from a time-slice simulation of Geophysical Fluid Dynamics Laboratory (GFDL) coupled chemistry-climate model AM3 (Donner et al., 2011; Naik et al., 2013) for the year 2010 following the configuration described by Naik et al. (2013). This AM3 simulation

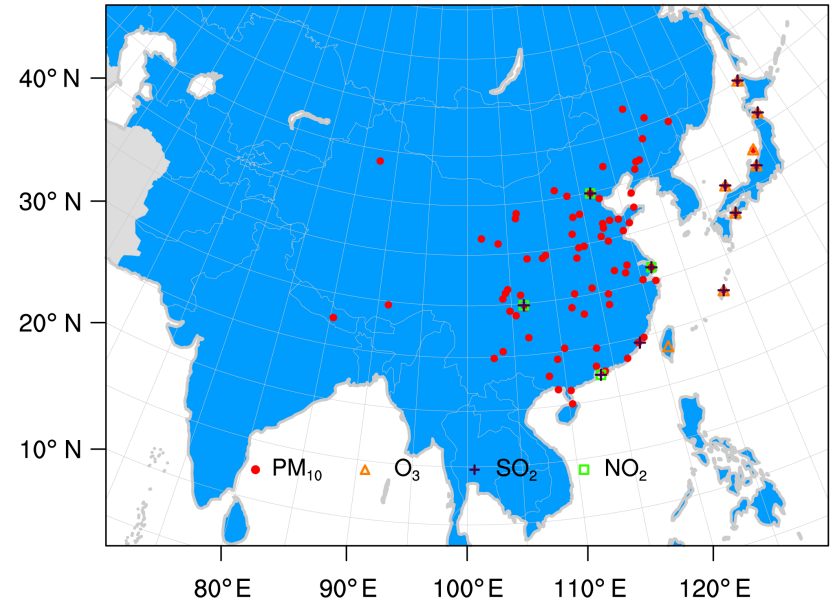

Figure 1. WRF-Chem model domain and observation sites. Blue shading indicates locations where the REAS emissions inventory is used. Gray shading indicates where the RCP8.5 emissions are used. For the entire model domain, biomass burning emissions from GFED v3 and biogenic emissions from POET v1 are used. Redfilled circles denote the observational sites with $\mathrm{PM}_{10}$; orange triangles sites with $\mathrm{O}_{3}$; purple crosses sites with $\mathrm{SO}_{2}$; and green squares sites with $\mathrm{NO}_{2}$.

was driven by climatological mean sea surface temperature and sea ice distributions for the 2006-2015 time period derived from the transient GFDL coupled model (GFDL-CM3) simulations following Representative Concentration Pathway 8.5 (RCP8.5) (John et al., 2012). Concentrations of wellmixed greenhouse gases and ozone-depleting substances, and emissions of short-lived pollutants (ozone precursors and aerosols) were set to year 2010 values in RCP8.5. We simulate air pollutant concentrations for the central month of each season (January, April, July, and October) in 2007, to assess seasonal variability in air quality. The model is spun up for 7 days before the beginning of each monthly simulation. This is sufficient to ventilate our regional domain.

\subsection{Emissions}

The anthropogenic emissions of gaseous pollutants $(\mathrm{CO}$, $\mathrm{NO}_{x}, \mathrm{NH}_{3}, \mathrm{SO}_{2}$, and NMVOCs) and particulate matter (BC, $\mathrm{OC}, \mathrm{PM}_{2.5}$, and $\mathrm{PM}_{10}$ ) are taken from REAS (Kurokawa et al., 2013). REAS covers most of the model domain (see Fig. 1, regions in blue). For the areas of our domain that are not covered by the REAS emissions inventory, we use the RCP8.5 emissions data set for the year 2010 (Riahi et al., 2011). The RCP8.5 emissions data set has been used in many studies for air quality simulations (Gao et al., 2013; Colette et al., 2013; Fry et al., 2012). For emissions from biomass burning, we use the year 2007 from the Global Fire Emissions Database version 3 (GFED) (Randerson et al., 2013). For biogenic emissions of $\mathrm{CO}, \mathrm{NO}_{x}$, and NMVOCs, as well as aircraft emissions of $\mathrm{CO}, \mathrm{NO}_{x}$, and $\mathrm{SO}_{2}$, we use the Pre- 
Table 1. List of total emissions for major pollutants from REAS and EDGAR over the model domain in July 2007. Unit is Tg month ${ }^{-1}$.

\begin{tabular}{lcccccc}
\hline Emissions inventory & $\mathrm{PM}_{10}$ & $\mathrm{CO}$ & $\mathrm{SO}_{2}$ & $\mathrm{NO}_{x}$ & NMVOCs & $\mathrm{NH}_{3}$ \\
\hline REAS & 2.73 & 25.05 & 4.62 & 4.61 & 3.67 & 2.61 \\
EDGAR & 3.07 & 21.25 & 4.62 & 3.33 & 4.56 & 1.69 \\
\hline
\end{tabular}
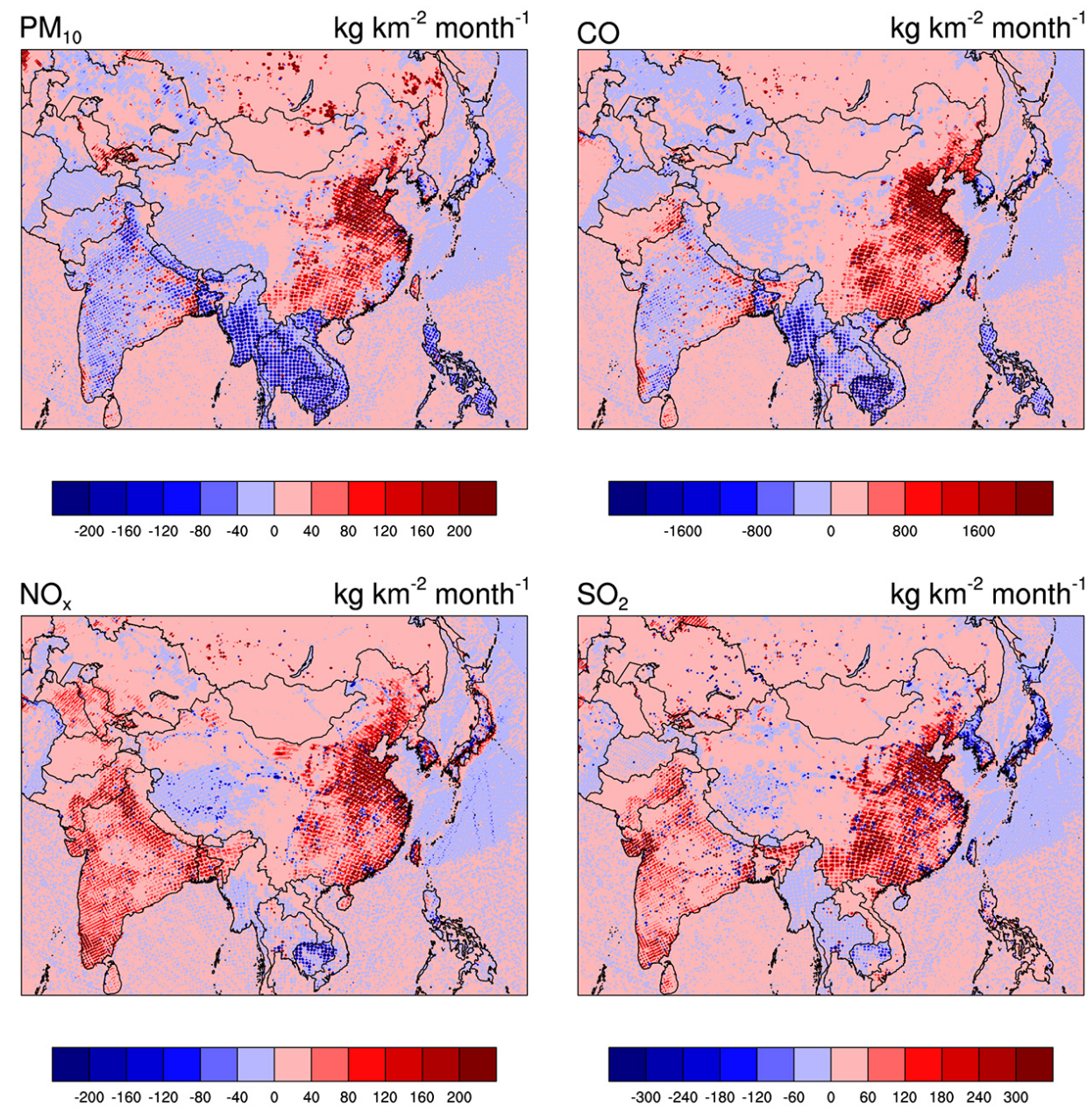

REAS-EDGAR

Figure 2. Monthly emissions difference of $\mathrm{PM}_{10}, \mathrm{CO}, \mathrm{SO}_{2}$, and $\mathrm{NO}_{x}$ between REAS and EDGAR in July 2007 in our model domain.

cursors of Ozone and their Effect on the Troposphere version 1 (POET) emissions inventory (Granier et al., 2005). Dust and sea salt emissions are calculated online using the dust transport model (Shaw et al., 2008) and sea salt (Gong, 2003) schemes, respectively.

To study the influence of anthropogenic emissions inventories on air quality simulation, we conducted a sensitivity simulation using the EDGAR (European Commission Joint Research Centre, 2010) inventory, as described in Sect. 3. EDGAR does not provide $\mathrm{BC}, \mathrm{OC}$, and $\mathrm{PM}_{2.5}$ emissions, and thus this study only compares simulated $\mathrm{O}_{3}$ and $\mathrm{PM}_{10}$. NMVOCs in EDGAR are also not speciated, so we di- vided them into 17 chemical species, using weighting factors calculated from REAS. The total anthropogenic emissions of each air pollutant within the model domain as estimated in REAS and EDGAR for July 2007 are listed in Table 1 . We apply the same diurnal variation to both REAS and EDGAR based on the East Asian Air Pollutant Emission Grid Database (EAGrid2000, http://www.cger.nies.go. jp/db/eagrid/eagrid_index_e.html). The ratios used to create hourly emissions for different pollutants are presented in Table S1 in the Supplement. The REAS emissions inventory provides monthly emissions for each pollutant, while the 

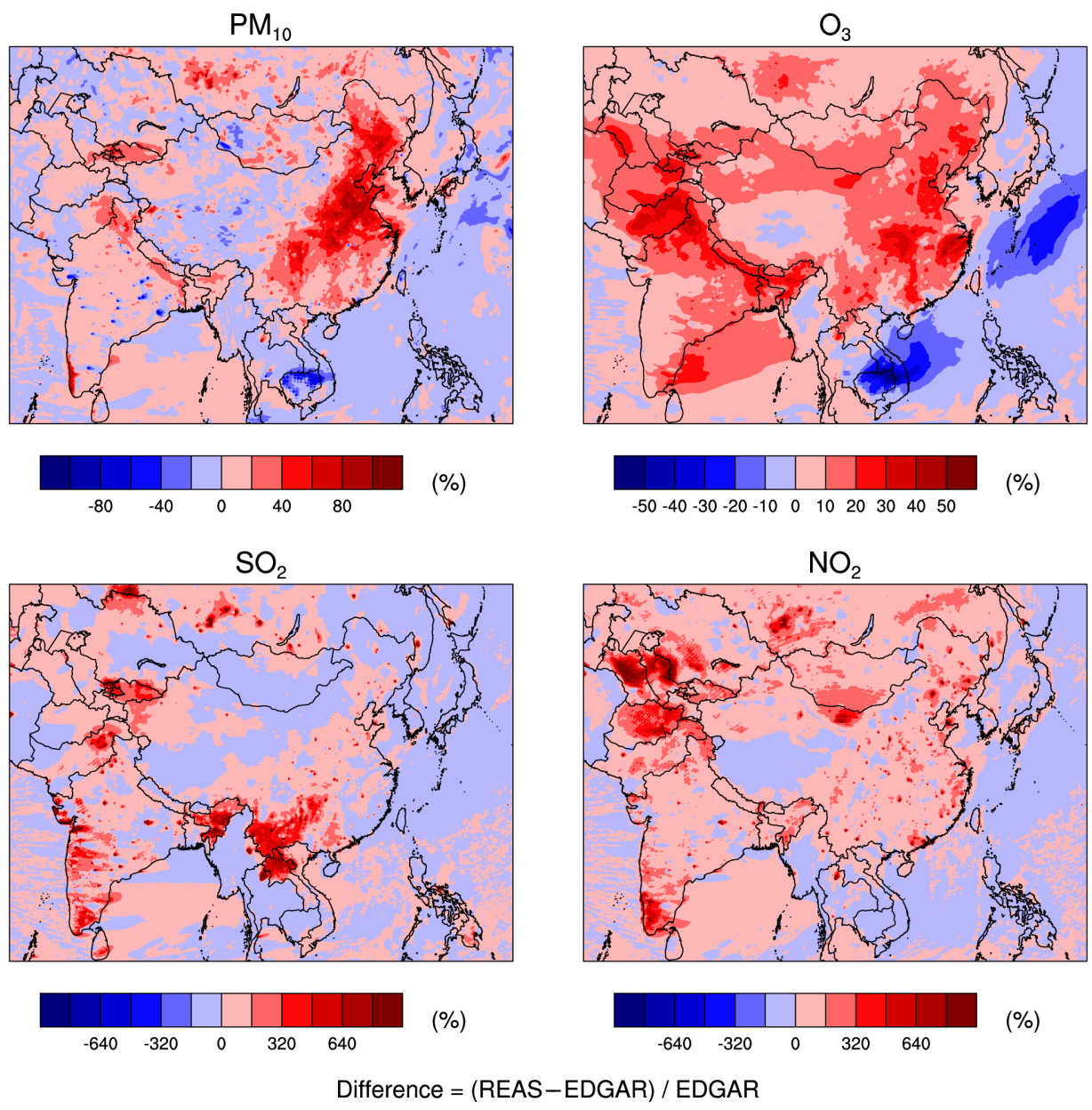

Figure 3. Percentage difference of 14-day mean $\mathrm{PM}_{10}, \mathrm{O}_{3}, \mathrm{SO}_{2}$, and $\mathrm{NO}_{2}$, between WRF-Chem simulations with REAS emissions (WRFChem-REAS) and EDGAR emissions (WRF-Chem-EDGAR).

EDGAR emissions inventory provides only yearly emissions estimates.

\subsection{Observations}

The surface concentrations of $\mathrm{PM}_{10}$ in China are derived from the Air Pollution Index (API) from the website of the Ministry of Environmental Protection of the People's Republic of China. When $\mathrm{PM}_{10}$ is reported as the primary pollutant with a maximum pollutant index, daily $\mathrm{PM}_{10}$ concentrations are calculated from the API, using the following equation:

$C=\left[\left(I-I_{\text {low }}\right) /\left(I_{\text {high }}-I_{\text {low }}\right)\right] \times\left(C_{\text {high }}-C_{\text {low }}\right)+C_{\text {low }}$,

where $C$ is the daily concentration of $\mathrm{PM}_{10}, I$ is the API reported, $I_{\text {low }}$ and $I_{\text {high }}$ are the lower and upper API breakpoints that $I$ falls within, and $C_{\text {low }}$ and $C_{\text {high }}$ are the $\mathrm{PM}_{10}$ concentrations corresponding to $I_{\text {low }}$ and $I_{\text {high }}$. Values of $I_{\text {low }}, I_{\text {high }}, C_{\text {low }}$, and $C_{\text {high }}$ are described for different API levels, as shown in Table S2. Qu et al. (2010) have shown that API-derived $\mathrm{PM}_{10}$ concentrations are generally comparable to those from filter sampling, although the latter tends to be approximately $10 \%$ higher than API-derived $\mathrm{PM}_{10}$. As mentioned earlier, the derived concentrations from API have been used for the evaluation of a different chemical transport model in previous studies (Wang et al., 2009; Liu et al., 2010).

The observed $\mathrm{PM}_{10}$ concentrations in Nepal are obtained from the Godavari station, located at the southern edge of the Kathmandu Valley (Ramanathan et al., 2007; Stone et al., 2010). We are unable to evaluate $\mathrm{PM}_{2.5}$ against measurements for 2007 since $\mathrm{PM}_{2.5}$ measurements in China started in late 2012. The observed $\mathrm{PM}_{10}, \mathrm{O}_{3}$, and $\mathrm{SO}_{2}$ in Japan and $\mathrm{SO}_{2}$ and $\mathrm{NO}_{2}$ in China are taken from the Acid Deposition Monitoring Network in East Asia (EANET). The surface mixing ratios of $\mathrm{O}_{3}$ in Mt. Lulin are taken from the Lulin Atmospheric Background Station (LABS, $2862 \mathrm{~m}$ above mean sea level) in central Taiwan (Ou Yang et al., 2012). The description of each site is listed in Table S3a-b; the locations of these sites are shown in Fig. 1. 

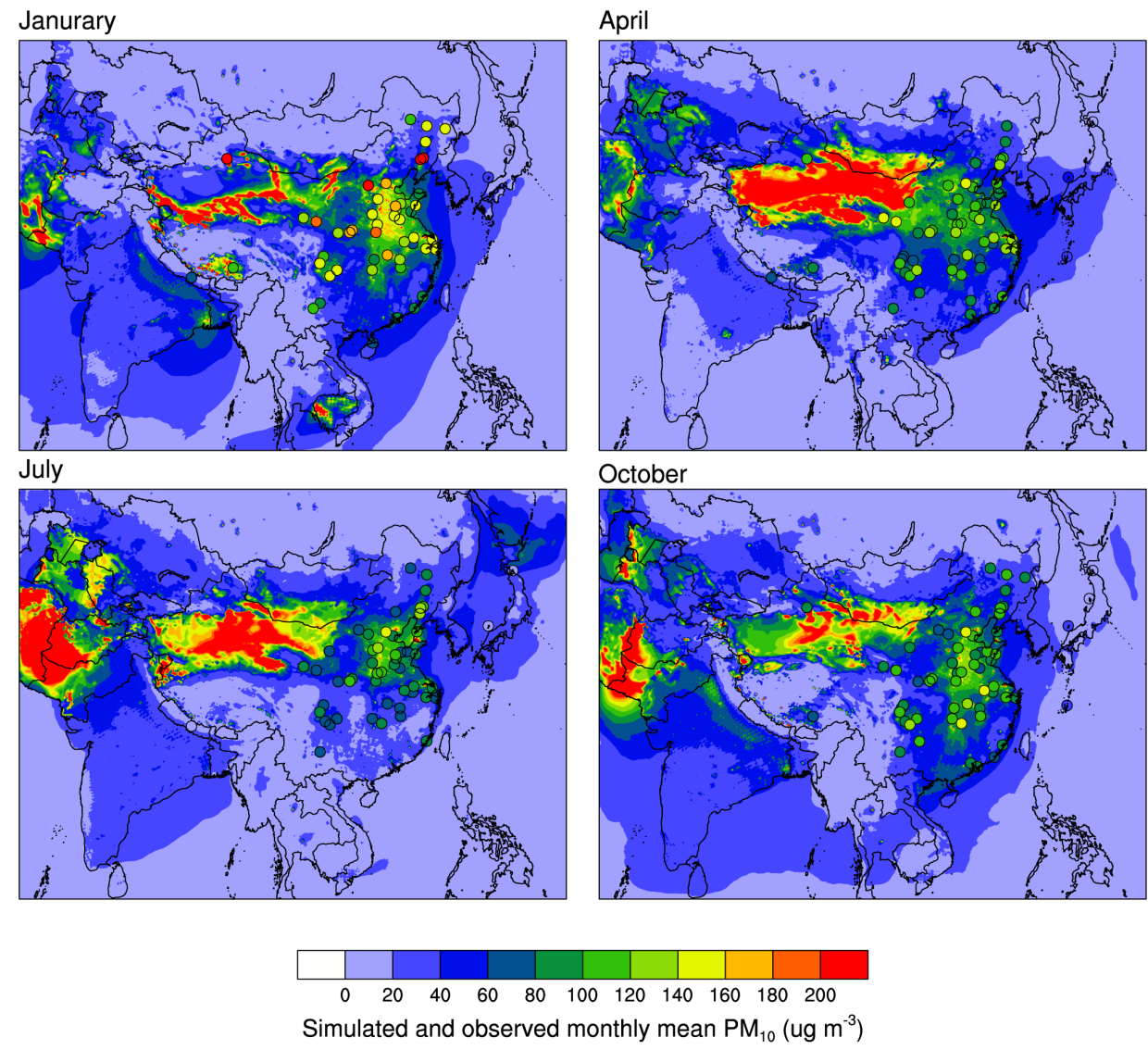

Figure 4. Simulated and observed monthly average surface $\mathrm{PM}_{10}$ in 2007 using WRF-Chem-REAS. The filled circles indicate the observed monthly average values.

\subsection{Data analysis method}

We assess the model performance using the correlation coefficient $(r)$, the normalized mean bias (NMB), the mean fractional bias (MFB), the mean fractional error (MFE), and the normalized mean square error (NMSE) between the observed (Obs) and modeled (Model) concentrations. The performance evaluation is based on monthly and yearly statistics using the daily mean values at each site, each region, and all sites. Following Boylan and Russell (2006), we set the performance goals of $\mathrm{PM}_{10}$ as MFB less than or equal to $\pm 30 \%$ and MFE less than or equal to $50 \%$. The performance criteria of $\mathrm{PM}_{10}$ are MFB $\leqslant \pm 60 \%$ and MFE $\leqslant 75 \%$. For $\mathrm{O}_{3}$, we use the performance benchmark MFB $\leqslant \pm 15 \%$ and MFE $\leqslant 35 \%$, as recommended by Morris et al. (2005).

\section{Sensitivity to emissions}

To better understand the effect that anthropogenic emissions have on regional air quality simulations, we conducted two simulations in which REAS and EDGAR are used as separate inputs. In the following sections, we compare the major pol- lutant emissions estimated in REAS and EDGAR, followed by comparisons of resulting air quality simulations.

\subsection{Emission comparisons}

Table 1 summarizes the total emissions of major air pollutants over the model domain in July 2007 for air pollutant precursors. Both REAS and EDGAR estimate similar total $\mathrm{SO}_{2}$ emissions of $4.62 \mathrm{Tg}$ month $^{-1}$. We note that this similarity is purely coincidental and depends on the domain. In certain parts of the domain the REAS estimate is higher than that of EDGAR, while the opposite is true for other parts of the domain. When averaged over the whole domain, both inventories produce similar estimates (Fig. 2). We, however, find large discrepancies between REAS and EDGAR estimated emissions for total $\mathrm{NH}_{3}(53 \%)$ and $\mathrm{NO}_{x}(27 \%)$. For $\mathrm{CO}, \mathrm{NH}_{3}$, and $\mathrm{NO}_{x}$, REAS estimates are higher than those of EDGAR, while for $\mathrm{PM}_{10}$ and NMVOCs, the opposite is the case. Figure 2 illustrates the difference in the spatial distribution and magnitude of emissions between REAS and EDGAR for $\mathrm{PM}_{10}, \mathrm{CO}, \mathrm{SO}_{2}$, and $\mathrm{NO}_{x}$ in our model domain. Although the total emissions within the domain for many of the species are comparable between the two inventories, the 

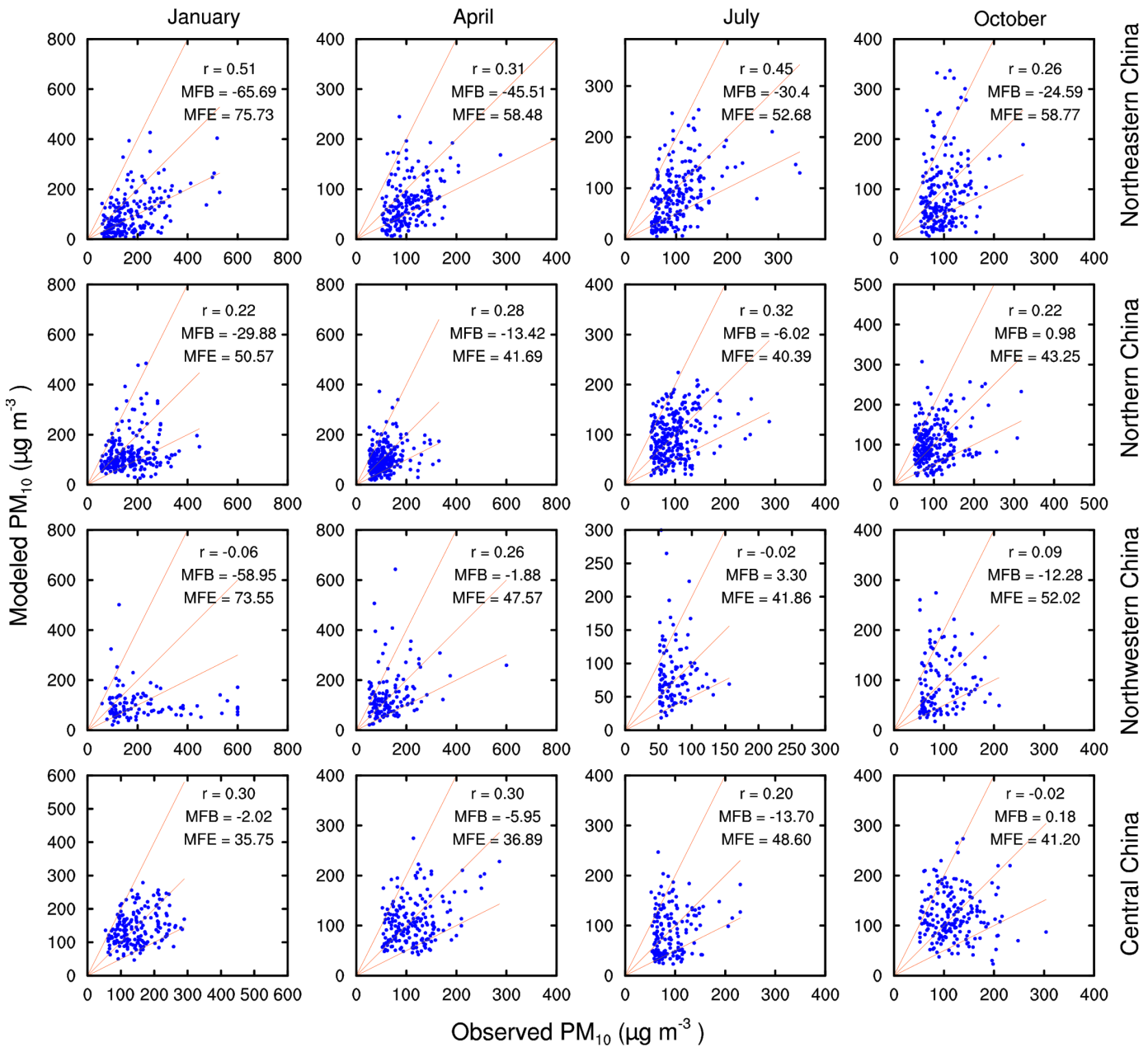

Figure 5. Comparisons of simulated and observed daily mean $\mathrm{PM}_{10}\left(\mu \mathrm{g} \mathrm{m}{ }^{-3}\right)$ in northeastern, northern, northwestern, and central China in each month. The model to observation ratios of $2: 1,1: 1$, and $1: 2$ are represented by orange lines. Monthly average performance statistics $(r, \mathrm{MFB}$, and MFE) are listed.

national and regional differences are large. REAS estimates are uniformly higher than those of EDGAR in northern, eastern, and southern China for all four species and in most parts of India for $\mathrm{NO}_{x}$ and CO. For $\mathrm{PM}_{10}$ and CO, EDGAR estimates are higher in most areas of South and Southeast Asia, as well as in Japan and South Korea. Table S4 compares the differences in provincial emissions between REAS and EDGAR in China. For example, we find that REAS estimates $150 \%$ higher $\mathrm{PM}_{10}$ and $548 \%$ higher $\mathrm{CO}$ emissions than EDGAR in Hebei province.

\subsection{Simulation comparisons}

For the convenience of discussion, we refer to the simulation with REAS emissions as WRF-Chem-REAS and the simulation using EDGAR emissions as WRF-Chem-EDGAR. Figure 3 illustrates the differences in the 14-day mean $\mathrm{PM}_{10}$, $\mathrm{O}_{3}, \mathrm{SO}_{2}$, and $\mathrm{NO}_{2}$ simulated from 1 to 14 July 2007 . The difference is presented as the percentage difference in concentrations or mixing ratios relative to those simulated in WRF-Chem-EDGAR. The pattern of the difference for these species is similar to that of the emissions difference. WRF-Chem-REAS simulates 40-70\% higher surface $\mathrm{PM}_{10}$ in most areas of the North China Plain (Beijing, Tianjin, Hebei, Henan, Shandong provinces). This difference, around $35 \mu \mathrm{g} \mathrm{m}^{-3}$ or higher, is comparable to the $\mathrm{PM}_{10}$ levels in many sites in Japan (Table 3). The highest difference (70 \%) occurs in Shandong province and the lowest difference (less than $\pm 5 \%$ ) is found in southwestern and northwestern China (Table S4). WRF-Chem-EDGAR simulates higher $\mathrm{PM}_{10}$ than WRF-Chem-REAS around Cambodia, Vietnam, and Thailand. For surface $\mathrm{O}_{3}$, a moderate difference of $16-20 \%$ (approximately 12-16 ppbv) is found over the North China Plain, the Yangtze River Delta, central China, and eastern Pakistan. WRF-Chem-REAS also results in higher $\mathrm{SO}_{2}$ and $\mathrm{NO}_{2}$ (more than $10 \mathrm{ppbv}$ ) in these areas than WRF-ChemEDGAR. The largest discrepancies, over $100 \%$, occur in 
Table 2. Statistical measures calculated for model simulations using REAS and EDGAR as emissions inputs for $\mathrm{PM}_{10}, \mathrm{O}_{3}, \mathrm{SO}_{2}$, and $\mathrm{NO}_{2} . r$ is the correlation coefficient between observations and model simulations; NMB (\%) is the normalized mean bias between observations and model simulations; MFB (\%) and MFE (\%) are the mean fractional bias and mean fractional error; NMSE is the normalized mean square error between the observations and model.

\begin{tabular}{|c|c|c|c|c|c|c|c|c|c|c|}
\hline \multirow[t]{2}{*}{ Pollutant } & \multicolumn{5}{|c|}{ REAS } & \multicolumn{5}{|c|}{ EDGAR } \\
\hline & $r$ & NMB & MFB & MFE & NMSE & $r$ & NMB & MFB & MFE & NMSE \\
\hline $\mathrm{PM}_{10}$ & 0.38 & -2.04 & -11.49 & 46.42 & 0.36 & 0.20 & -27.28 & -37.34 & 56.70 & 0.58 \\
\hline $\mathrm{O}_{3}$ & 0.83 & 19.11 & 24.50 & 30.95 & 0.10 & 0.82 & 19.20 & 25.24 & 32.33 & 0.10 \\
\hline $\mathrm{SO}_{2}$ & 0.72 & 138.64 & 51.60 & 84.93 & 3.58 & 0.64 & 98.42 & 70.38 & 94.09 & 2.03 \\
\hline $\mathrm{NO}_{2}$ & 0.68 & -18.32 & -22.50 & 50.98 & 0.41 & 0.66 & -59.88 & -71.52 & 83.05 & 1.57 \\
\hline
\end{tabular}

Table 3. Statistical performance of WRF-Chem-REAS simulations for $\mathrm{PM}_{10}$ in 2007. Count is the total number of observations for calculation; Obs $\left(\mu \mathrm{g} \mathrm{m}^{-3}\right)$ and Model $\left(\mu \mathrm{g} \mathrm{m}^{-3}\right)$ are 4-month mean daily average value of observations and model simulations, respectively. Other indicators and associated units are described in Table 2.

\begin{tabular}{lrrrrrrrr}
\hline Region & Count & Obs & Model & $r$ & NMB & MFB & MFE & NMSE \\
\hline Central China & 726 & 117.45 & 114.21 & 0.32 & -2.75 & -5.23 & 40.47 & 0.25 \\
Eastern China & 1908 & 103.05 & 102.41 & 0.28 & -0.63 & -3.85 & 38.05 & 0.31 \\
Northern China & 1068 & 116.35 & 105.35 & 0.30 & -9.45 & -11.52 & 43.65 & 0.39 \\
Northeastern China & 826 & 119.07 & 87.83 & 0.39 & -26.24 & -41.15 & 61.26 & 0.59 \\
Northwestern China & 462 & 126.86 & 105.80 & 0.13 & -16.60 & -16.54 & 53.39 & 0.95 \\
Southern China & 452 & 82.74 & 68.97 & 0.18 & -16.64 & -22.27 & 44.68 & 0.31 \\
Southwestern China & 934 & 95.24 & 63.13 & 0.35 & -33.72 & -47.61 & 59.21 & 0.51 \\
Japan & 409 & 25.44 & 20.83 & 0.27 & -18.10 & -32.34 & 65.24 & 2.00 \\
Nepal & 89 & 49.63 & 21.15 & 0.29 & -57.38 & -47.89 & 75.07 & 2.10 \\
\hline \multirow{2}{*}{ All sites } & 6874 & 102.46 & 89.15 & 0.39 & -12.99 & -19.95 & 48.40 & 0.46 \\
\hline
\end{tabular}

Guizhou (220\%) and Yunnan (175\%) provinces for $\mathrm{SO}_{2}$, and in Shanghai $(258 \%)$ and Shandong $(118 \%)$ provinces for $\mathrm{NO}_{2}$.

Table 2 summarizes the statistical measures of model simulations using these two anthropogenic emissions inventories against observations. Both simulations reproduce the temporal variation of $\mathrm{O}_{3}, \mathrm{SO}_{2}$, and $\mathrm{NO}_{2}$ well, with the value of $r$ between 0.64 and 0.83 . The temporal correlation of $\mathrm{PM}_{10}$ for WRF-Chem-REAS $(r=0.38)$ is higher than that calculated for WRF-Chem-EDGAR $(r=0.2)$. In terms of bias, both simulations produce a similar NMB and MFB for $\mathrm{O}_{3}$. For $\mathrm{PM}_{10}, \mathrm{NO}_{2}$, and $\mathrm{SO}_{2}$, WRF-Chem-REAS has a smaller MFB than WRF-Chem-EDGAR. In terms of error, MFE and NMSE from the two simulations are comparable for $\mathrm{O}_{3}$, but WRF-Chem-REAS results in less MFE and NMSE for $\mathrm{PM}_{10}$ and $\mathrm{NO}_{2}$. According to the model performance goals and criteria of $\mathrm{PM}_{10}$ suggested by Boylan and Russell (2006), WRF-Chem-EDGAR meets the performance criteria, while WRF-Chem-REAS achieves the stricter performance goals. We have conducted additional sensitivity simulations using REAS and EDGAR in January and July and compared the simulated air pollutants and observation. The results of these 2-month simulations (not shown here) agree with what we find here.
Based on the above performance analyses, we choose REAS as the anthropogenic emissions inventory to conduct further simulations for 4 months to explore the seasonality of air pollutant concentrations. In this paper, we focus on validating the WRF-Chem model with REAS.

\section{Spatiotemporal variations of pollutants and model evaluation}

In this section, we analyze the spatial variability of simulated and observed monthly mean $\mathrm{PM}_{10}$ concentrations, as well as $\mathrm{O}_{3}, \mathrm{SO}_{2}$, and $\mathrm{NO}_{x}$ mixing ratios (Figs. 4, 7, 9, and 10). A color-filled circle overlaid on a model-simulated monthly average surface concentration map represents the observed monthly average value at each site. Tables 3-6 describe yearly statistics for $\mathrm{PM}_{10}$ concentrations, as well as $\mathrm{O}_{3}, \mathrm{SO}_{2}$, and $\mathrm{NO}_{2}$ mixing ratios at individual stations, respectively. Table $\mathrm{S} 7$ summarizes seasonal statistics for the same pollutants at all available stations. The comparisons between daily modeled and observed concentrations of each pollutant are given in Figs. 5, 6, 8, and 11 for individual sites. Detailed analyses of model biases and errors for each of the species are provided in the following subsections. 
Table 4. Statistical performance of WRF-Chem-REAS simulations for $\mathrm{O}_{3}$ in 2007. The unit of Obs and Model is ppbv. Other statistical indicators and associated units are described in Table 2.

\begin{tabular}{llrrrrrrrr}
\hline Location & Sites & Count & Obs & Model & $r$ & NMB & MFB & MFE & NMSE \\
\hline \multirow{2}{*}{ Japan } & Happo & 81 & 61.04 & 55.57 & 0.55 & -8.95 & -7.30 & 20.57 & 0.06 \\
& Hedo & 90 & 39.59 & 45.79 & 0.93 & 15.68 & 20.60 & 22.42 & 0.04 \\
& Oki & 99 & 43.72 & 50.19 & 0.60 & 14.81 & 16.01 & 20.18 & 0.06 \\
& Rishiri & 54 & 47.14 & 46.12 & 0.03 & -2.16 & -0.92 & 15.41 & 0.03 \\
& Sado-seki & 82 & 46.24 & 47.85 & 0.61 & 3.48 & 4.59 & 12.13 & 0.02 \\
& Tappi & 101 & 51.75 & 45.95 & 0.56 & -11.21 & -9.84 & 17.65 & 0.05 \\
& Yusuhara & 102 & 42.80 & 47.68 & 0.75 & 11.40 & 12.75 & 17.31 & 0.04 \\
\hline \multirow{2}{*}{ Taiwan } & Lulin & 94 & 30.89 & 44.89 & 0.62 & 45.34 & 41.31 & 44.05 & 0.23 \\
\hline \multirow{2}{*}{ All sites } & & 703 & 45.05 & 47.98 & 0.67 & 6.51 & 10.48 & 21.62 & 0.06 \\
\hline
\end{tabular}

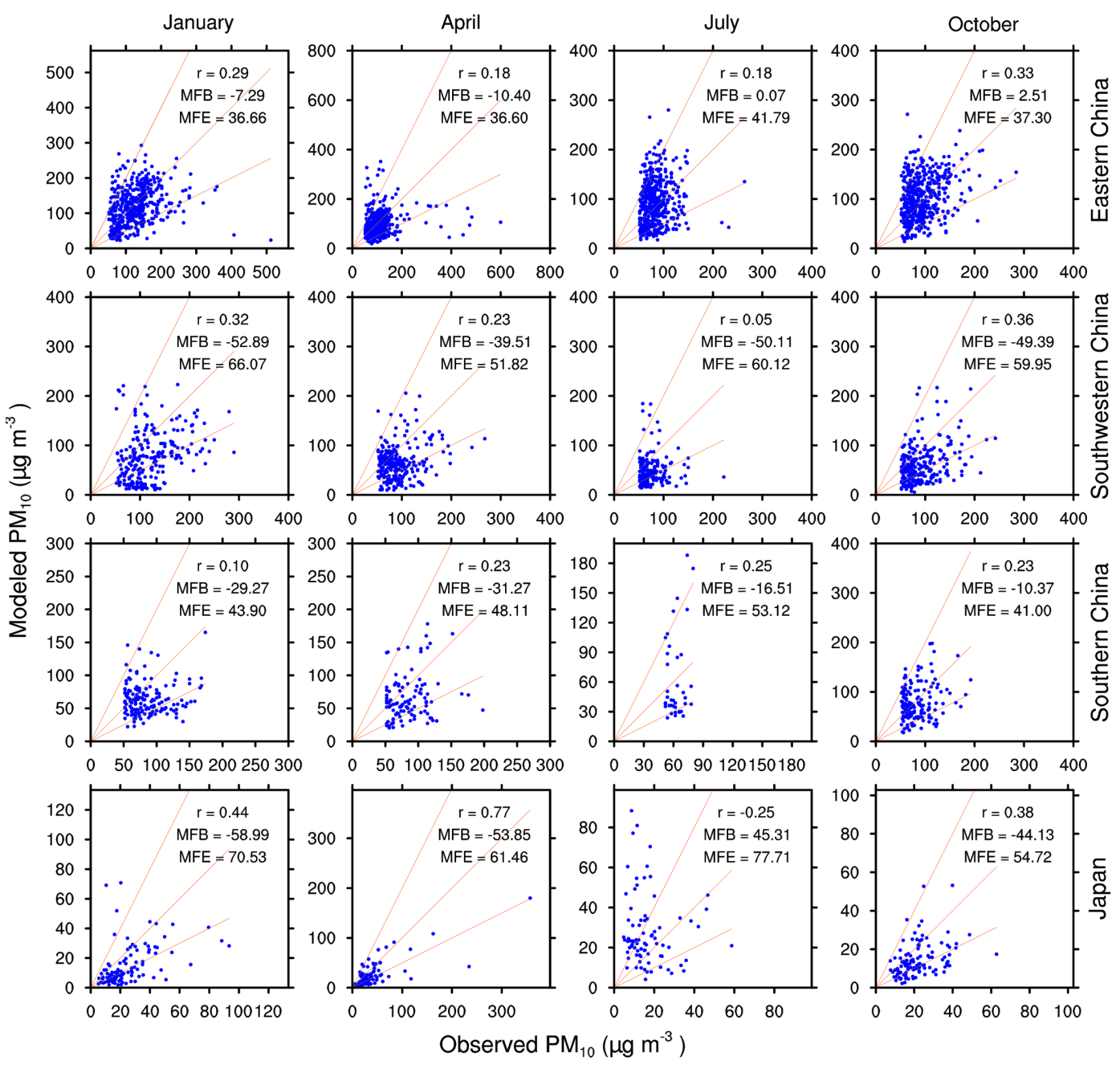

Figure 6. Comparisons of simulated and observed daily mean $\mathrm{PM}_{10}\left(\mu \mathrm{g} \mathrm{m}^{-3}\right)$ in eastern, southwestern, and southern China, and Japan in each month. The model to observation ratios of $2: 1,1: 1$, and $1: 2$ are represented by orange lines. Monthly average performance statistics $(r, \mathrm{MFB}$, and MFE) are listed. 
Table 5. Statistical performance of WRF-Chem-REAS simulations for $\mathrm{SO}_{2}$ in 2007. The unit of Obs and Model is ppbv. Other statistical indicators and associated units are described in Table 2.

\begin{tabular}{|c|c|c|c|c|c|c|c|c|c|}
\hline Location & Sites & Count & Obs & Model & $r$ & NMB & MFB & MFE & NMSE \\
\hline \multirow[t]{6}{*}{ Japan } & Happo & 65 & 0.60 & 0.72 & 0.53 & 19.27 & 20.96 & 77.56 & 1.23 \\
\hline & Hedo & 86 & 0.51 & 0.37 & 0.66 & -27.57 & -12.17 & 69.44 & 1.70 \\
\hline & Oki & 89 & 0.85 & 0.82 & 0.52 & -3.60 & 29.31 & 69.73 & 1.77 \\
\hline & Rishiri & 50 & 0.23 & 0.22 & 0.71 & -2.90 & 17.84 & 55.33 & 0.46 \\
\hline & Tappi & 97 & 0.43 & 0.37 & 0.65 & -13.66 & -1.71 & 51.61 & 0.78 \\
\hline & Yusuhara & 99 & 1.27 & 1.26 & 0.82 & -0.59 & 26.55 & 63.58 & 0.72 \\
\hline \multirow[t]{5}{*}{ China } & Xiamen & 122 & 11.79 & 4.90 & 0.14 & -58.42 & -70.79 & 81.26 & 1.62 \\
\hline & Jinyunshan & 123 & 10.10 & 17.81 & 0.50 & 76.34 & 62.19 & 75.48 & 0.85 \\
\hline & Zhuhai & 123 & 6.88 & 8.16 & 0.29 & 18.74 & 5.27 & 52.50 & 0.67 \\
\hline & Beijing & 123 & 15.65 & 21.74 & 0.32 & 38.92 & 63.38 & 91.86 & 1.05 \\
\hline & Shanghai & 123 & 22.71 & 30.57 & 0.38 & 34.57 & 20.10 & 51.59 & 0.56 \\
\hline \multicolumn{2}{|c|}{ All sites } & 1100 & 7.80 & 8.82 & 0.64 & 13.06 & 8.89 & 65.80 & 1.52 \\
\hline
\end{tabular}
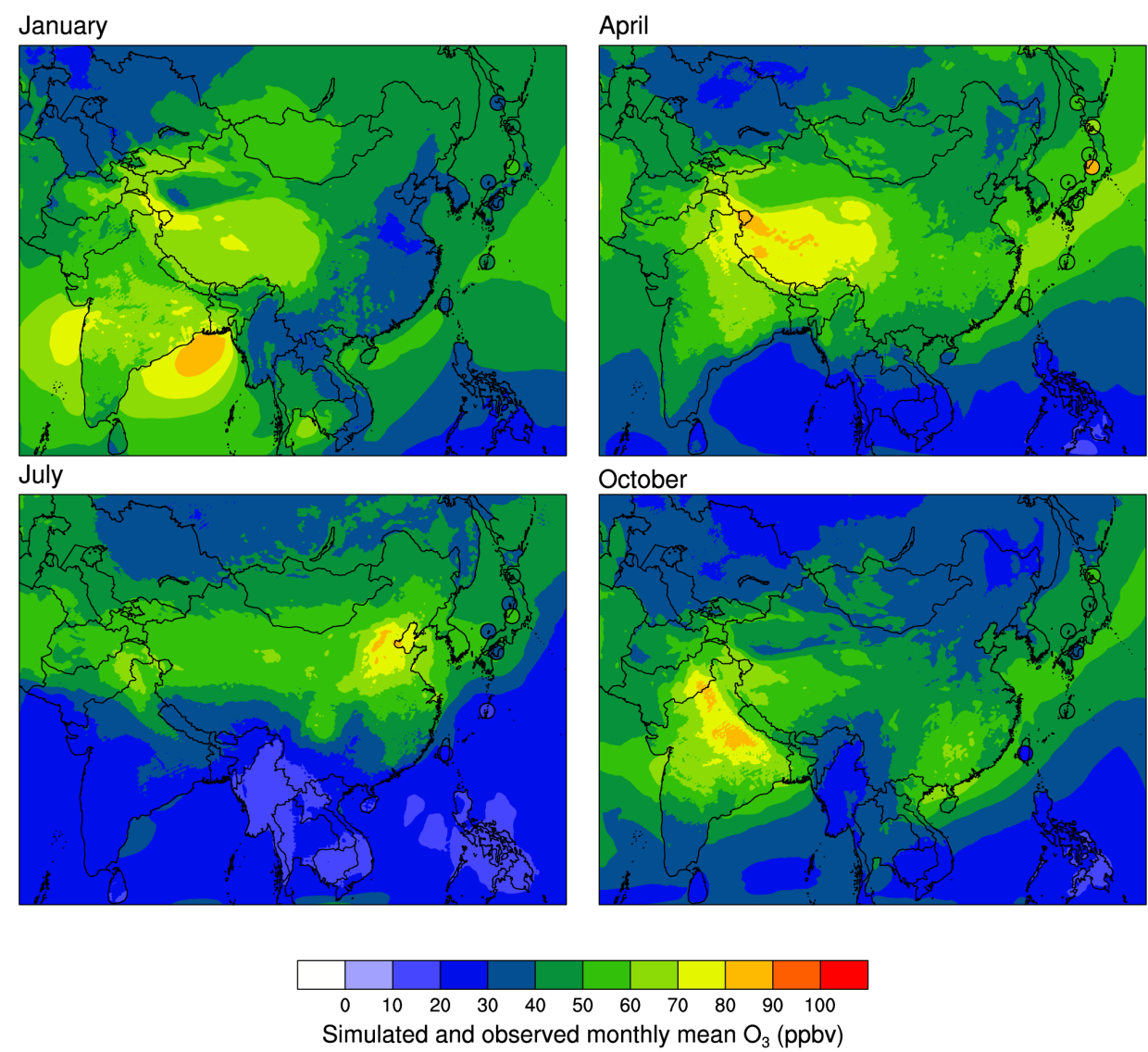

Figure 7. Simulated and observed monthly average surface $\mathrm{O}_{3}$ in 2007 using WRF-Chem-REAS. The filled circles indicate the observed monthly average values.

Before analyzing the model performance in simulating air pollutants, we evaluate the simulated meteorological fields, including daily mean $2 \mathrm{~m}$ temperature, $2 \mathrm{~m}$ relative humidity, and $10 \mathrm{~m}$ wind speed against observations from the National Climate Data Center of China Meteorological Administra- tion for the year 2007 (Table S5). The model reproduces $2 \mathrm{~m}$ temperature with a correlation of 0.97 and a negative NMB of $-14.57 \%$. Relative humidity is simulated with a correlation of 0.71 and a positive NMB of $7.02 \%$. Compared to temperature and relative humidity, the $10 \mathrm{~m}$ wind speed has 
a relatively lower correlation of 0.52 and a higher positive NMB of $59.35 \%$. Overall, the model performance in simulating these meteorological data is similar to that reported for regional air quality models (Tuccella et al., 2012; Tessum et al., 2015; Zhang et al., 2015).

\section{1 $\mathbf{P M}_{10}$}

We obtain ground-level measurements from 1 site in Nepal, 7 sites in Japan, and 71 sites in China. China is divided into seven geographical regions and measurements are analyzed based on these regions (Table 3). The coverage of each geographical region in China is shown in Fig. S1. In China, the highest 4-month average $\mathrm{PM}_{10}$ is observed in northwestern China $\left(126 \pm 94 \mu \mathrm{g} \mathrm{m}^{-3}\right)$, followed by northeastern $\left(119 \pm 65 \mu \mathrm{g} \mathrm{m}^{-3}\right)$ and central China $\left(117 \pm 48 \mu \mathrm{g} \mathrm{m}^{-3}\right)$, while the lowest observed $\mathrm{PM}_{10}$ is in southern China $\left(82 \pm 28 \mu \mathrm{g} \mathrm{m}^{-3}\right)$. In Japan, the observed 4-month average $\mathrm{PM}_{10}$ concentration is $27 \pm 33 \mu \mathrm{g} \mathrm{m}^{-3}$, which is more than 3 times lower than those observed in China.

The model simulates high $\mathrm{PM}_{10}$ concentrations (over $200 \mathrm{\mu g} \mathrm{m}^{-3}$ ) near the Gobi Desert in northwestern China and in the border area near Iran, Afghanistan, and Pakistan (Fig. 4). In these areas, dust emissions are the predominant source of $\mathrm{PM}_{10}$ and the anthropogenic primary $\mathrm{PM}_{10}$ is negligible, as shown in Fig. S2. Besides these areas, the model simulates high $\mathrm{PM}_{10}$ concentrations (up to $100 \mu \mathrm{g} \mathrm{m}^{-3}$ ) over the North China Plain, the Yangtze River Delta region, and the Sichuan Basin. The model simulates relatively low $\mathrm{PM}_{10}$ concentrations (lower than $60 \mu \mathrm{g} \mathrm{m}^{-3}$ ) in most of southern, southwestern, and northeastern China, most of India, and other countries in the model domain. Unlike northwestern China, where the maximum $\mathrm{PM}_{10}$ concentrations are simulated in spring, other regions of China are simulated to have high concentrations in January and October, with low concentrations in April and July. This is because in winter, reduced precipitation leads to higher $\mathrm{PM}_{10}$ concentrations, while the monsoon circulation brings in clean marine air and dilutes the $\mathrm{PM}_{10}$ surface concentrations in eastern China in summer. Moreover, aerosols in summer are removed by wet scavenging due to more frequent precipitation (Zhao et al., 2010). High concentrations are also simulated in an area surrounding Lhasa in Tibet in January. Since primary anthropogenic emissions in Tibet are low, dust emissions from local soils on the plateau are the main reason for high $\mathrm{PM}_{10}$ concentrations. The previous study of tracer element analyses has shown that local dust is the major source of total particulate matter (PM) over Tibet (Zhang et al., 2001).

For 4-month averaged $\mathrm{PM}_{10}$, the model meets the performance criteria at $84 \%$ of observation sites in China. The model tends to underestimate observations at the rest of the sites, which are mainly located in northeastern and southwestern China. Analyzing model-observation comparison by region, we find better model performance in central, eastern, northern, and southern China (Table 3). However, north-
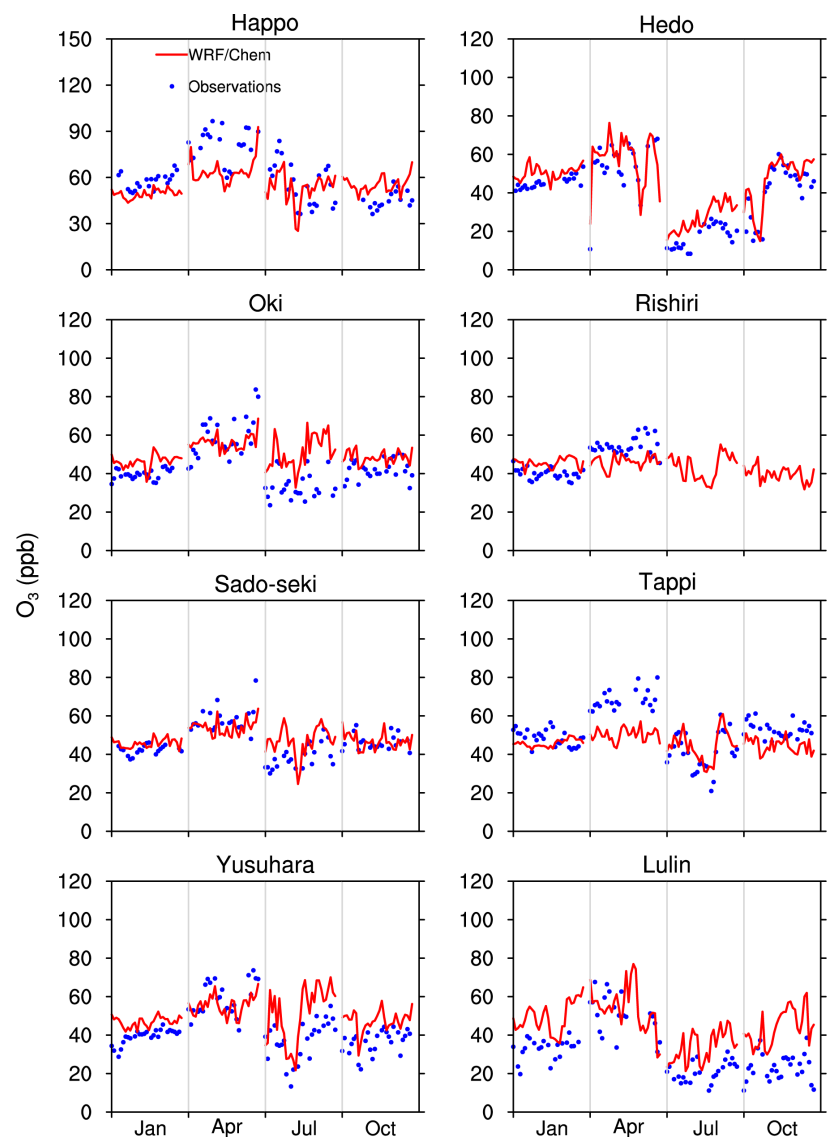

Figure 8. Comparisons of observed (blue dots) and modeled (red lines) daily mean $\mathrm{O}_{3}$ (ppbv) at seven sites in Japan and one site in Taiwan.

eastern and southwestern China have a higher correlation $(r>0.35)$ than others. For sites outside of China, the model underestimates observations in both Japan (MFB $=-32 \%)$ and Nepal (MFB $=-48 \%$ ).

The seasonal statistics (Table S6) and Figs. 5-6 indicate that the model meets the performance criteria in all 4 months (January, April, July, and October) in central, eastern, northern, and southern China. In the remaining regions in China and Japan, the model meets or is close to the criteria in April, July, and October, but has more difficulty reproducing $\mathrm{PM}_{10}$ concentrations in January. Previous research has suggested that poor model performance in winter is common among air quality models and may be caused by difficulty in simulating stagnant weather conditions that lead to high winter PM concentrations (Tessum et al., 2015). In Nepal, model performance in both January and April is poor when the observed $\mathrm{PM}_{10}$ is high. The time series comparison plots (Fig. S3) reveal distinct air pollution episodes occurring in middle January and early April at the Godavari site, which the model fails to simulate. One of the possible reasons for this is that the model is unable to reproduce the local meteorology due to the complicated topography that is not well resolved at 
Table 6. Statistical performance of WRF-Chem-REAS simulations for $\mathrm{NO}_{2}$ in 2007. The unit of Obs and Model is ppbv. Other statistical indicators and associated units are described in Table 2.

\begin{tabular}{|c|c|c|c|c|c|c|c|c|c|}
\hline Location & Sites & Count & Obs & Model & $r$ & NMB & MFB & MFE & NMSE \\
\hline \multirow[t]{4}{*}{ China } & Beijing & 123 & 32.17 & 18.63 & 0.47 & -42.09 & -53.69 & 58.67 & 0.48 \\
\hline & Shanghai & 123 & 29.45 & 30.57 & 0.21 & 3.81 & -9.26 & 46.65 & 0.41 \\
\hline & Jinyunshan & 123 & 7.04 & 2.82 & 0.34 & -59.89 & -74.42 & 87.77 & 2.16 \\
\hline & Zhuhai & 123 & 19.42 & 7.97 & 0.11 & -58.95 & -82.08 & 86.11 & 1.34 \\
\hline \multicolumn{2}{|c|}{ All sites } & 492 & 36.78 & 15.00 & 0.56 & -31.88 & -54.86 & 69.80 & 0.69 \\
\hline
\end{tabular}
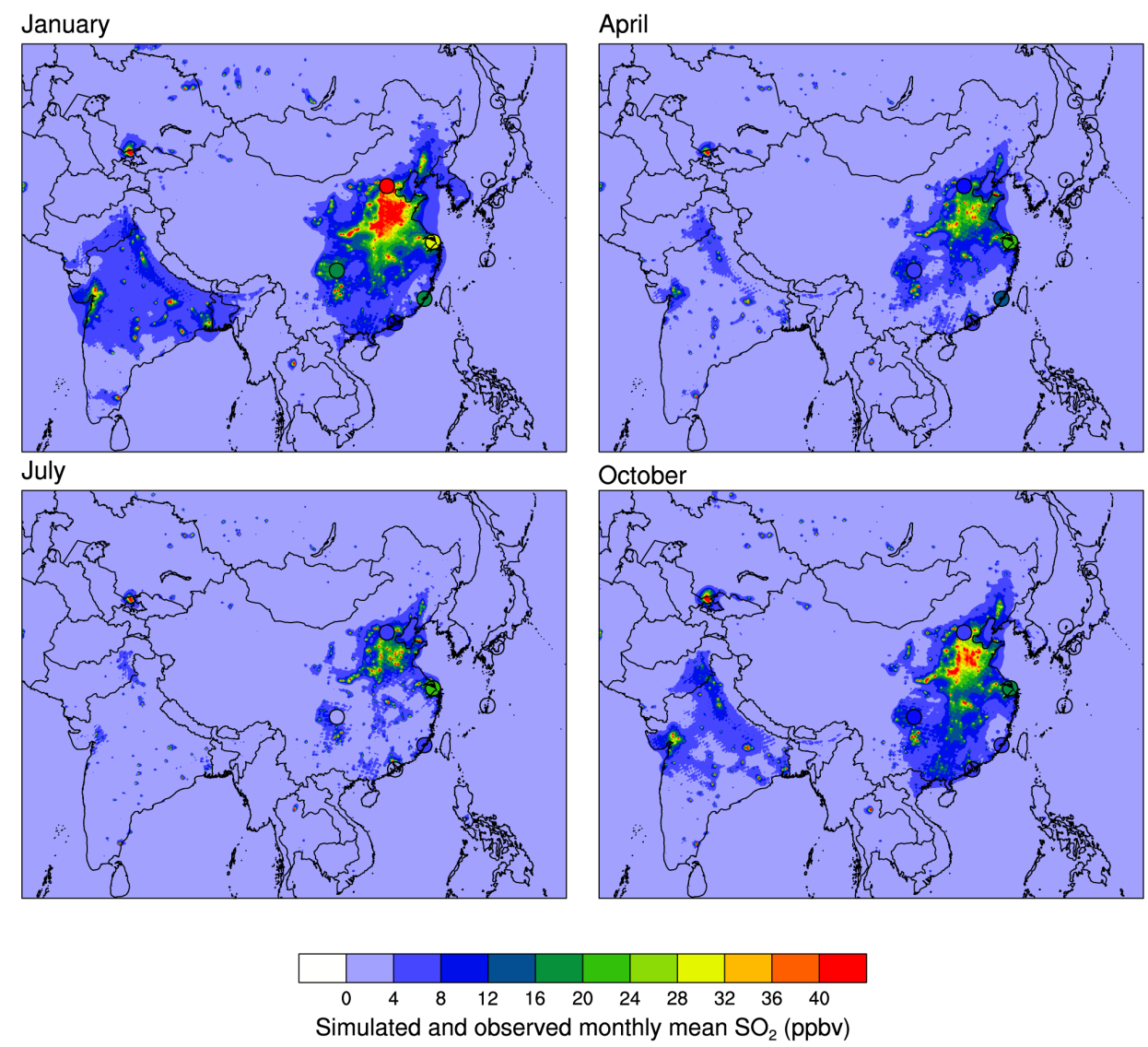

Figure 9. Simulated and observed monthly average surface $\mathrm{SO}_{2}$ in 2007 using WRF-Chem-REAS. The filled circles indicate the observed monthly average values.

the current horizontal resolution. The temporal correlations of all sites in each month are similar $(0.37-0.39)$ as shown in Table S7 and we do not observe obvious trends of temporal correlation change with seasons.

\section{$\begin{array}{lll}4.2 & \mathrm{O}_{3}\end{array}$}

Similar to $\mathrm{PM}_{10}$, the simulated $\mathrm{O}_{3}$ over the model domain also exhibits a seasonal variability that varies by region. Figure 7 illustrates that the highest $\mathrm{O}_{3}$ mixing ratio (over 70 ppbv) occurs in northern and eastern China in July. This is because biogenic NMVOC emissions are relatively high and active photochemical reactions constitute favorable conditions for the build-up of $\mathrm{O}_{3}$ mixing ratios in summer. On the other hand, a low monthly mean mixing ratio (below $40 \mathrm{ppbv}$ ) is found in the same region in January. In the Tibetan Plateau, the surface $\mathrm{O}_{3}$ mixing ratio reaches a maximum (over $70 \mathrm{ppbv}$ ) in April due to high elevations and downward transport of $\mathrm{O}_{3}$ from the stratosphere, while the minimum $\mathrm{O}_{3}(40 \mathrm{ppbv})$ is found in July because the upward transport of air to the stratosphere in the summer suppresses the downward transport of $\mathrm{O}_{3}$ (Gettelman et al., 2004; Randel et al., 2010). This simulated seasonal variability of $\mathrm{O}_{3}$ 

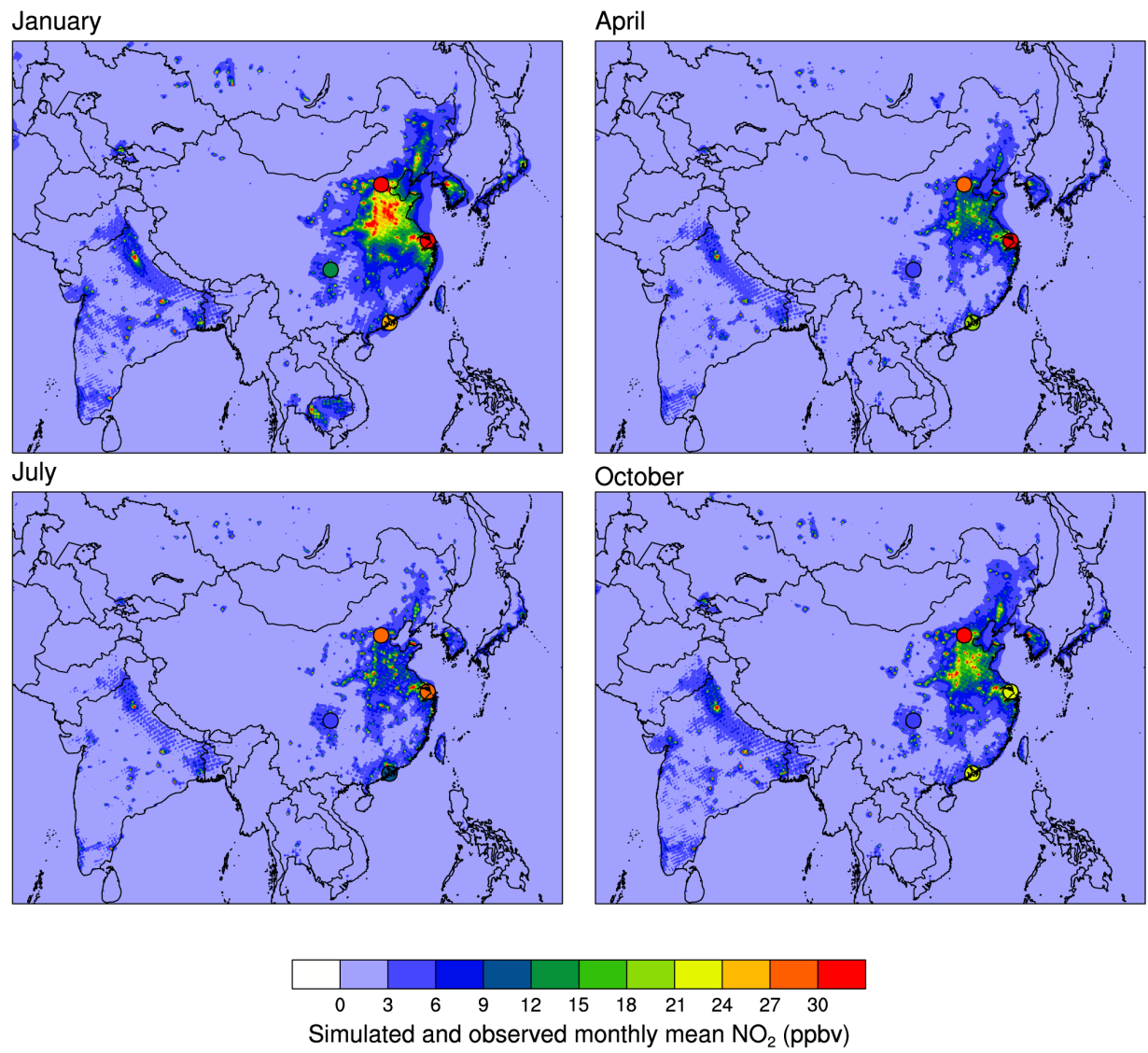

Figure 10. Simulated and observed monthly average surface $\mathrm{NO}_{2}$ in 2007 using WRF-Chem-REAS. The filled circles indicate the observed monthly average values.

in our model over the Tibetan Plateau is consistent with the findings of Ma et al. (2014).

The model performs well for simulating $\mathrm{O}_{3}$ at all sites in Japan, and both MFB and MFE of these sites are within or close to the model benchmark (MFB $< \pm 15 \%$ and MFE $<35 \%$ ). The model overestimates $\mathrm{O}_{3}$ at Lulin in Taiwan. MFB at Lulin (41\%) is more than 2 times higher than that of any sites in Japan. Statistical analysis of $\mathrm{O}_{3}$ in different seasons at the Lulin site (Table S8) reveals that such high bias is mainly caused by overestimation in October $(\mathrm{MFB}=63 \%)$. A previous study by Ou Yang et al. (2012) suggested that Lulin has more pronounced mountain valley circulation in fall, which leads to low observed $\mathrm{O}_{3}$ mixing ratios in October. Our model with a horizontal resolution of $20 \mathrm{~km} \times 20 \mathrm{~km}$ may not be able to capture such local meteorology. The model reproduces the overall daily temporal variation of $\mathrm{O}_{3}$ well $(r=0.57)$ and the value of temporal correlation is also high for each site (0.47-0.93), except at Rishiri. This is partly due to the lateral boundary conditions, since this site is located close to the northeastern boundary of the model domain. The model predicts the seasonal variability well, as shown in Fig. 8 and Table S7. The modeled and observed monthly mean $\mathrm{O}_{3}$ has a maximum in April and a min- imum in July. The same seasonal characteristics of $\mathrm{O}_{3}$ levels were reported before (Yamaji et al., 2006). The MFB and MFE of all sites in each month are in the acceptable range. Among the 4 months, the model tends to underestimate the highest observations in April, while it overestimates observations in the other 3 months.

\section{$4.3 \quad \mathrm{SO}_{2}$ and $\mathrm{NO}_{2}$}

Figure 9 illustrates that the model simulates a high monthly mean $\mathrm{SO}_{2}$ mixing ratio (higher than $20 \mathrm{ppbv}$ ) over urban areas in northern China (including Beijing, Tianjin, Hebei, and Shanxi) and some provinces in eastern China (including Shandong and Henan), where emissions are also the highest. In these areas, the mixing ratios are the highest in January, followed by October, April, and July (Fig. 9). The lowest mixing ratios in our model simulation are found in July due to more active oxidation of $\mathrm{SO}_{2}$ by hydroxyl radical $(\mathrm{OH})$ and $\mathrm{O}_{3}$ in the gas phase, as well as frequent precipitation that favors aqueous-phase oxidation of $\mathrm{SO}_{2}$ (Feichter et al., 1996). Overall, the model predicts $\mathrm{SO}_{2}$ well, with a MFB of $9 \%$ and $r$ of 0.64 . The model performs better in predicting observed $\mathrm{SO}_{2}$ mixing ratios at sites in Japan $(\mathrm{MFB}=-12$ 

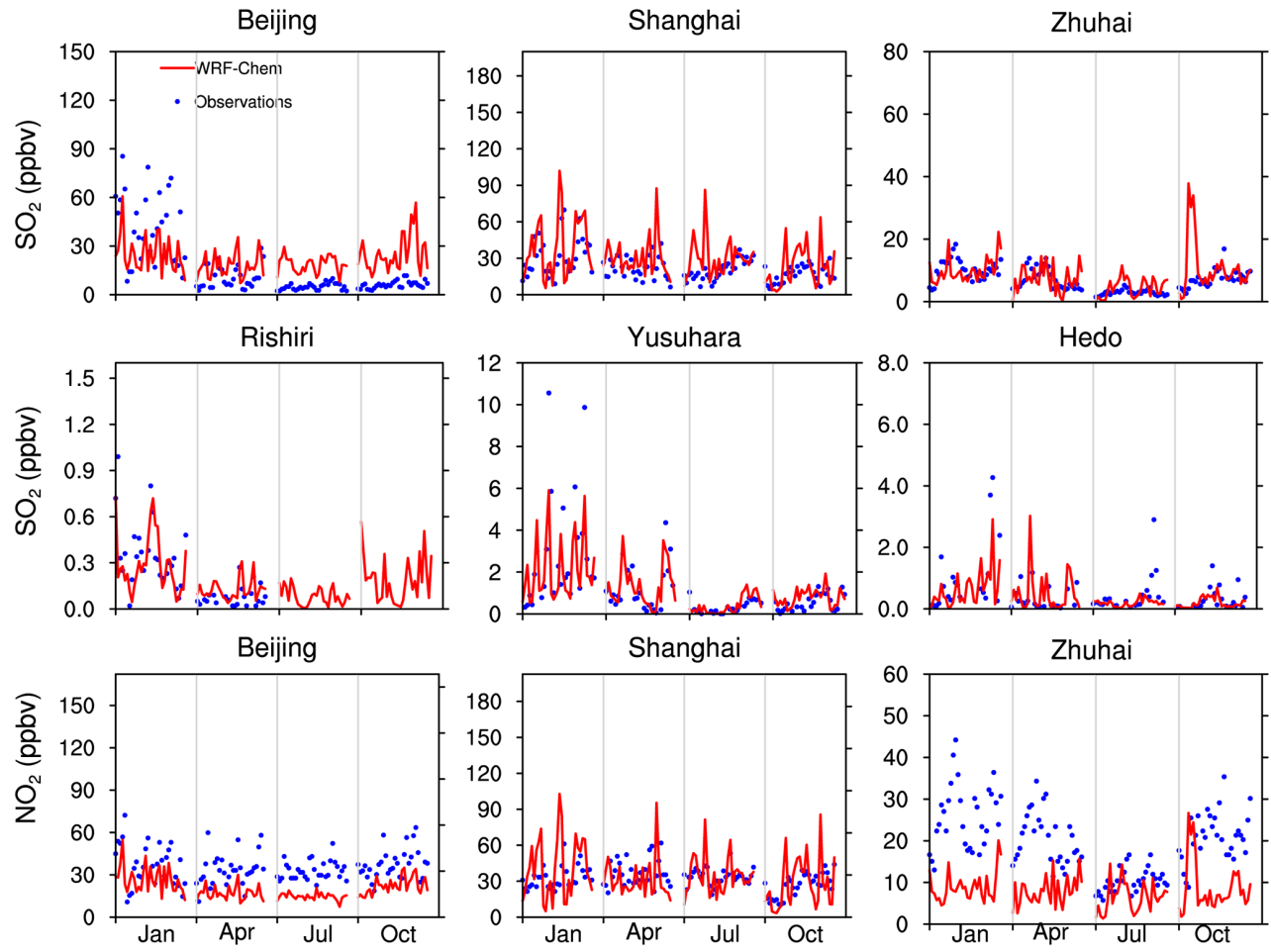

Figure 11. Comparisons of observed (blue dots) and modeled (red lines) daily mean $\mathrm{SO}_{2}$ (ppbv) at six sites in China and Japan and $\mathrm{NO}_{2}$ (ppbv) at three sites in China.

to $29 \%, r=0.52-0.82)$ than in China (MFB $=-70$ to $63 \%$, $r=0.14-0.5)$. The lowest overall MFB value of all sites occurs in April (8\%), while the highest happens in July (31\%). Although MFB values are acceptable, both the MFE and NMSE in July and October are high. The site that contributes most to high errors is Beijing, with a MFE of more than $115 \%$ in these 2 months. The model largely overestimates $\mathrm{SO}_{2}$ in Beijing (Fig. 11), probably because the REAS emissions inventory did not take into account the local emissions control policies for the Beijing Olympics. In 2007, the Chinese government reduced anthropogenic emissions by shutting down many polluting industries, banning high-emission vehicles, and restricting the number of on-road vehicles in Beijing (Zhang et al., 2012). It is likely that our emissions were overestimated in Beijing, which caused a large discrepancy between modeled and observed $\mathrm{SO}_{2}$ mixing ratios.

The spatial and seasonal distribution of $\mathrm{NO}_{2}$ is similar to $\mathrm{SO}_{2}$ as shown in Fig. 10. A high $\mathrm{NO}_{2}$ mixing ratio is found over northeastern, northern, and eastern China due to high emissions from the power plant, industry and transportation sectors in these regions. Outside China, several hotspots are identified, such as Seoul (South Korea) and New Delhi (India). The modeled $\mathrm{NO}_{2}$ mixing ratios have a summer minimum and a winter maximum. The lifetime of $\mathrm{NO}_{2}$ in winter is relatively longer $(18-24 \mathrm{~h})$ than that in summer $(6 \mathrm{~h})$ because the concentration of hydroxyl radical $(\mathrm{OH})$ in the atmosphere is low (Beirle et al., 2003). Consequently, the re- moval reaction of $\mathrm{NO}_{2}$ with $\mathrm{OH}$ radicals to form $\mathrm{HNO}_{3}$ is less active in winter than in summer. Among the four sites in China, the model performs well in predicting observed $\mathrm{NO}_{2}$ mixing ratios at the Shanghai site $(\mathrm{MFB}=-9 \%)$; however, it underestimates at the other three sites (MFB $>-53 \%$ ). WRF-Chem captures the seasonal variability of $\mathrm{NO}_{2}$, but underestimates the monthly average of $\mathrm{NO}_{2}$, with a MFB between -41 and $-68 \%$ for all 4 months. Underestimation of $\mathrm{NO}_{2}$ has also been reported in the South Asian region using WRF-Chem (Kumar et al., 2012) and a possible reason was proposed as the underestimation of $\mathrm{NO}_{x}$ emissions from biomass burning or anthropogenic sources. Another potential reason is that the removal of $\mathrm{NO}_{x}$ was overestimated through the heterogeneous reaction of $\mathrm{N}_{2} \mathrm{O}_{5}$ to form nitric acid in the RADM2 WRF-Chem chemical mechanism (Yegorova et al., 2011), used in this study.

\section{Conclusions}

We performed WRF-Chem simulation of air quality over East and South Asia using two different anthropogenic emissions inventories and evaluated the model performance for $\mathrm{PM}_{10}$ concentrations, as well as $\mathrm{O}_{3}, \mathrm{SO}_{2}$, and $\mathrm{NO}_{2}$ mixing ratios, using ground-level observations for the year 2007. We find that large discrepancies exist between the extensively used EDGAR global anthropogenic emissions and the 
REAS regional inventory at national and provincial scales. The discrepancies between these inventories can lead to large differences in simulated surface $\mathrm{PM}_{10}$ concentrations (40$70 \%)$ and moderate differences in $\mathrm{O}_{3}$ mixing ratios (16$20 \%$ ) in most areas of the North China Plain, as well as more than $100 \%$ differences in $\mathrm{SO}_{2}$ and $\mathrm{NO}_{2}$ mixing ratios, found in several provinces in China. Our study demonstrates that WRF-Chem is sensitive to emissions inventories and improvements in emissions inventories are important for accurately simulating regional air quality. Further studies are needed to assess model performance differences due to different emission inputs.

On the basis of lower bias and error values versus observations we found for our WRF-Chem-REAS simulations, we chose the REAS inventory to conduct four 1-month simulations for the purpose of model evaluation. The model results indicate clear regional variations in the seasonal cycle of surface $\mathrm{PM}_{10}$ and $\mathrm{O}_{3}$ over East and South Asia. In northwestern China, maximum $\mathrm{PM}_{10}$ occurs in April, while in Nepal and other regions of China, the highest $\mathrm{PM}_{10}$ mainly occurs in January. For surface $\mathrm{O}_{3}$ mixing ratios, the peak values are simulated in July for northern and eastern China, and in April for Tibet and Japan. Comparisons between model simulations and observations show that the model performs well in simulating surface $\mathrm{PM}_{10}$ and $\mathrm{O}_{3}$, meeting air quality model performance criteria for both $\mathrm{PM}_{10}$ and $\mathrm{O}_{3}$ at most sites, although the model underestimates $\mathrm{PM}_{10}$ at some sites in China in January. The model predicts $\mathrm{SO}_{2}$ better at sites in Japan than in China, where overestimation is large at the Beijing site in July and October. The model underestimates most observed $\mathrm{NO}_{2}$ in all 4 months.

Quantifying uncertainties of simulated air quality at the provincial level due to emission inputs reveals that the uncertainty in emissions inventories leads to significant differences in simulated levels of air pollutants, especially $\mathrm{PM}_{10}, \mathrm{SO}_{2}$, and $\mathrm{NO}_{2}$. For $\mathrm{O}_{3}$, on the other hand, different emissions inventories lead to only a moderate variability, showing agreement with the findings of previous studies (Ma and van Aardenne, 2004; Amnuaylojaroen et al., 2014). Our study highlights the importance of better constraining emissions at the provincial level for regional air quality modeling over East Asia, where anthropogenic emissions are high and air pollution is a major environmental and public health challenge. Model evaluation results also indicate that emissions inventories that do not consider local emissions control policies could cause large discrepancies. Our results suggest that future work should focus on better constraining the provinciallevel emissions especially estimating the primary $\mathrm{PM}, \mathrm{SO}_{2}$, and $\mathrm{NO}_{x}$.

\section{Code availability}

The WRF-Chem model is an open-source, publicly available, and continually improved software. Version 3.5 used in this study can be downloaded at http://www2.mmm. ucar.edu/wrf/users/download/get_source.html. Known problems of the WRF-Chem version 3.5 have been fixed, using solutions provided online at http://ruc.noaa.gov/wrf/WG11/ known-prob_v3.5.htm. We have optimized dust parameterizations in the code, using observed ground-level $\mathrm{PM}_{10}$ concentrations. The modified code can be obtained from the corresponding authors.

\section{The Supplement related to this article is available online at doi:10.5194/gmd-9-1201-2016-supplement.}

Acknowledgements. The NCEP GFS data used for this study are from the Research Data Archive (RDA), which is maintained by the Computational and Information Systems Laboratory (CISL) at the National Center for Atmospheric Research (NCAR). The data are available at http://rda.ucar.edu/datasets/ds083.2/ (National Centers for Environmental Prediction, National Weather Service, NOAA, US Department of Commerce, 2000). We thank Keiichi Sato at the Asia Center for Air Pollution Research for providing EANET data. Ambient aerosol measurements in Godavari, Nepal, were supported by Pradeep Dangol and Bidya Banmali Pradhan of the International Center for Integrated Mountain Development and James Schauer of the University of Wisconsin-Madison, and were funded through the United Nations Environmental Programme and the National Oceanic and Atmospheric Administration. This study was supported by the Energy Foundation (grant number G-1208-16644) and the National Science Foundation (grant number AGS-1350021). We gratefully acknowledge Songmiao Fan and the two anonymous reviewers for providing constructive suggestions.

Edited by: G. A. Folberth

\section{References}

Ackermann, I. J., Hass, H., Memmesheimer, M., Ebel, A., Binkowski, F. S., and Shankar, U.: Modal aerosol dynamics model for Europe: development and first applications, Atmos. Environ., 32, 2981-2999, doi:10.1016/S1352-2310(98)00006-5, 1998.

Amnuaylojaroen, T., Barth, M. C., Emmons, L. K., Carmichael, G. R., Kreasuwun, J., Prasitwattanaseree, S., and Chantara, S.: Effect of different emission inventories on modeled ozone and carbon monoxide in Southeast Asia, Atmos. Chem. Phys., 14, 12983-13012, doi:10.5194/acp-14-12983-2014, 2014.

Beirle, S., Platt, U., Wenig, M., and Wagner, T.: Weekly cycle of $\mathrm{NO}_{2}$ by GOME measurements: a signature of anthropogenic sources, Atmos. Chem. Phys., 3, 2225-2232, doi:10.5194/acp3-2225-2003, 2003.

Binkowski, F. S. and Shankar, U.: The Regional Particulate Matter Model: 1. Model description and preliminary results, J. Geophys. Res.-Atmos., 100, 26191-26209, doi:10.1029/95JD02093, 1995.

Boylan, J. W. and Russell, A. G.: PM and light extinction model performance metrics, goals, and criteria for threedimensional air quality models, Atmos. Environ., 40, 49464959, doi:10.1016/j.atmosenv.2005.09.087, 2006. 
Chapman, E. G., Gustafson Jr., W. I., Easter, R. C., Barnard, J. C., Ghan, S. J., Pekour, M. S., and Fast, J. D.: Coupling aerosolcloud-radiative processes in the WRF-Chem model: Investigating the radiative impact of elevated point sources, Atmos. Chem. Phys., 9, 945-964, doi:10.5194/acp-9-945-2009, 2009.

Chen, Z., Wang, J.-N., Ma, G.-X., and Zhang, Y.-S.: China tackles the health effects of air pollution, The Lancet, 382, 1959-1960, 2013.

Colette, A., Bessagnet, B., Vautard, R., Szopa, S., Rao, S., Schucht, S., Klimont, Z., Menut, L., Clain, G., Meleux, F., Curci, G., and Rouill, L.: European atmosphere in 2050, a regional air quality and climate perspective under CMIP5 scenarios, Atmos. Chem. Phys., 13, 7451-7471, doi:10.5194/acp-13-7451-2013, 2013.

Donner, L. J., Wyman, B. L., Hemler, R. S., Horowitz, L. W., Ming, Y., Zhao, M., Golaz, J.-C., Ginoux, P., Lin, S. J., Schwarzkopf, M. D., Austin, J., Alaka, G., Cooke, W. F., Delworth, T. L., Freidenreich, S. M., Gordon, C. T., Griffies, S. M., Held, I. M., Hurlin, W. J., Klein, S. A., Knutson, T. R., Langenhorst, A. R., Lee, H.-C., Lin, Y., Magi, B. I., Malyshev, S. L., Milly, P. C. D., Naik, V., Nath, M. J., Pincus, R., Ploshay, J. J., Ramaswamy, V., Seman, C. J., Shevliakova, E., Sirutis, J. J., Stern, W. F., Stouffer, R. J., Wilson, R. J., Winton, M., Wittenberg, A. T., and Zeng, F.: The Dynamical Core, Physical Parameterizations, and Basic Simulation Characteristics of the Atmospheric Component AM3 of the GFDL Global Coupled Model CM3, J. Climate, 24, 34843519, doi:10.1175/2011JCLI3955.1, 2011.

Easter, R. C., Ghan, S. J., Zhang, Y., Saylor, R. D., Chapman, E. G., Laulainen, N. S., Abdul-Razzak, H., Leung, L. R., Bian, X., and Zaveri, R. A.: MIRAGE: Model description and evaluation of aerosols and trace gases, J. Geophys. Res.-Atmos., 109, D20210, doi:10.1029/2004JD004571, 2004.

Feichter, J., Kjellström, E., Rodhe, H., Dentener, F., Lelieveldi, J., and Roelofs, G.-J.: Simulation of the tropospheric sulfur cycle in a global climate model, Atmos. Environ., 30, 1693-1707, doi:10.1016/1352-2310(95)00394-0, 1996.

Fry, M. M., Naik, V., West, J. J., Schwarzkopf, M. D., Fiore, A. M., Collins, W. J., Dentener, F. J., Shindell, D. T., Atherton, C., Bergmann, D., Duncan, B. N., Hess, P., MacKenzie, I. A., Marmer, E., Schultz, M. G., Szopa, S., Wild, O., and Zeng, G.: The influence of ozone precursor emissions from four world regions on tropospheric composition and radiative climate forcing, J. Geophys. Res.-Atmos., 117, D07306, doi:10.1029/2011JD017134, 2012.

Gao, Y., Fu, J. S., Drake, J. B., Lamarque, J.-F., and Liu, Y.: The impact of emission and climate change on ozone in the United States under representative concentration pathways (RCPs), Atmos. Chem. Phys., 13, 9607-9621, doi:10.5194/acp-13-96072013, 2013.

Gao, Y., Zhao, C., Liu, X., Zhang, M., and Leung, L. R.: WRFChem simulations of aerosols and anthropogenic aerosol radiative forcing in East Asia, Atmos. Environ., 92, 250-266, doi:10.1016/j.atmosenv.2014.04.038, 2014.

Gettelman, A., Kinnison, D. E., Dunkerton, T. J., and Brasseur, G. P.: Impact of monsoon circulations on the upper troposphere and lower stratosphere, J. Geophys. Res.-Atmos., 109, D22101, doi:10.1029/2004JD004878, 2004.

Gong, S. L.: A parameterization of sea-salt aerosol source function for sub- and super-micron particles, Global Biogeochem. Cy., 17, 1097, doi:10.1029/2003GB002079, 2003.
Granier, C., Lamarque, J. F., Mieville, A., Muller, J. F., Olivier, J., Orlando, J., Peters, J., Petron, G., Tyndall, G., and Wallens, S.: POET, a database of surface emissions of ozone precursors, available at: http://www.aero.jussieu.fr/projet/ACCENT/POET. php (last access: 25 October 2013), 2005.

Grell, G. A. and Dévényi, D.: A generalized approach to parameterizing convection combining ensemble and data assimilation techniques, Geophys. Res. Lett., 29, 38-1-38-4, doi:10.1029/2002GL015311, 2002.

Grell, G. A., Peckham, S. E., Schmitz, R., McKeen, S. A., Frost, G., Skamarock, W. C., and Eder, B.: Fully coupled "online" chemistry within the WRF model, Atmos. Environ., 39, 6957-6975, doi:10.1016/j.atmosenv.2005.04.027, 2005.

HEI: Outdoor air pollution among top global health risks in 2010, available at: http://www.healtheffects.org/International/ HEI-India-GBD-PressRelease021313.pdf (last access: 20 May 2014), 2013.

John, J. G., Fiore, A. M., Naik, V., Horowitz, L. W., and Dunne, J. P.: Climate versus emission drivers of methane lifetime against loss by tropospheric OH from 1860-2100, Atmos. Chem. Phys., 12, 12021-12036, doi:10.5194/acp-12-12021-2012, 2012.

JRC and PBL: Emission Database for Global Atmospheric Research (EDGAR), version 4.2., European Commission, Joint Research Centre/PBL Netherlands Environmental Assessment Agency, available at: http://edgar.jrc.ec.europa.eu (last access: 19 March 2014), 2010.

Klimont, Z., Cofala, J., Xing, J., Wei, W., Zhang, C., Wang, S., Kejun, J., Bhandari, P., Mathur, R., Purohit, P., Rafaj, P., Chambers, A., Amann, M., and Hao, J.: Projections of $\mathrm{SO}_{2}, \mathrm{NO}_{x}$ and carbonaceous aerosols emissions in Asia, Tellus B, 61, 602-617, doi:10.1111/j.1600-0889.2009.00428.x, 2011.

Kong, X., Forkel, R., Sokhi, R. S., Suppan, P., Baklanov, A., Gauss, M., Brunner, D., Barò, R., Balzarini, A., Chemel, C., Curci, G., Jiménez-Guerrero, P., Hirtl, M., Honzak, L., Im, U., Pérez, J. L., Pirovano, G., Jose, R. S., Schlünzen, K. H., Tsegas, G., Tuccella, P., Werhahn, J., Žabkar, R., and Galmarini, S.: Analysis of meteorology-chemistry interactions during air pollution episodes using online coupled models within AQMEII phase-2, Atmospheric Environment, 115, 527-540, doi:10.1016/j.atmosenv.2014.09.020, 2015.

Kumar, R., Naja, M., Pfister, G. G., Barth, M. C., Wiedinmyer, C., and Brasseur, G. P.: Simulations over South Asia using the Weather Research and Forecasting model with Chemistry (WRFChem): chemistry evaluation and initial results, Geosci. Model Dev., 5, 619-648, doi:10.5194/gmd-5-619-2012, 2012.

Kurokawa, J., Ohara, T., Morikawa, T., Hanayama, S., JanssensMaenhout, G., Fukui, T., Kawashima, K., and Akimoto, H.: Emissions of air pollutants and greenhouse gases over Asian regions during 2000-2008: Regional Emission inventory in ASia (REAS) version 2, Atmos. Chem. Phys., 13, 11019-11058, doi:10.5194/acp-13-11019-2013, 2013.

Lin, Y.-L., Farley, R. D., and Orville, H. D.: Bulk Parameterization of the Snow Field in a Cloud Model, Journal of Climate and Applied Meteorology, 22, 1065-1092, doi:10.1175/15200450(1983)022<1065:BPOTSF>2.0.CO;2, 1983.

Liu, X.-H., Zhang, Y., Cheng, S.-H., Xing, J., Zhang, Q., Streets, D. G., Jang, C., Wang, W.-X., and Hao, J.-M.: Understanding of regional air pollution over China using CMAQ, part I perfor- 
mance evaluation and seasonal variation, Atmos. Environ., 44, 2415-2426, doi:10.1016/j.atmosenv.2010.03.035, 2010.

Ma, J. and van Aardenne, J. A.: Impact of different emission inventories on simulated tropospheric ozone over China: a regional chemical transport model evaluation, Atmos. Chem. Phys., 4, 877-887, doi:10.5194/acp-4-877-2004, 2004.

Ma, J., Lin, W. L., Zheng, X. D., Xu, X. B., Li, Z., and Yang, L. L.: Influence of air mass downward transport on the variability of surface ozone at Xianggelila Regional Atmosphere Background Station, southwest China, Atmos. Chem. Phys., 14, 5311-5325, doi:10.5194/acp-14-5311-2014, 2014.

Mlawer, E. J., Taubman, S. J., Brown, P. D., Iacono, M. J., and Clough, S. A.: Radiative transfer for inhomogeneous atmospheres: RRTM, a validated correlated-k model for the longwave, J. Geophys. Res.-Atmos., 102, 16663-16682, doi:10.1029/97JD00237, 1997.

Morris, R., Koo, B., McNally, D., Tesche, T., and Tonnesen, G.: Application of Multiple Models to Simulation Fine Particulate in the Southeastern US Presented at the National Regional Planning Organizations Modeling Meeting, Denver, CO, 2005.

Naik, V., Horowitz, L. W., Fiore, A. M., Ginoux, P., Mao, J., Aghedo, A. M., and Levy, H.: Impact of preindustrial to presentday changes in short-lived pollutant emissions on atmospheric composition and climate forcing, J. Geophys. Res.-Atmos., 118, 8086-8110, doi:10.1002/jgrd.50608, 2013.

National Centers for Environmental Prediction, National Weather Service, NOAA, US Department of Commerce: NCEP FNL Operational Model Global Tropospheric Analyses, continuing from July 1999, Research Data Archive at the National Center for Atmospheric Research, Computational and Information Systems Laboratory, Boulder CO, doi:10.5065/D6M043C6, 2000.

Ou Yang, C.-F., Lin, N.-H., Sheu, G.-R., Lee, C.-T., and Wang, J.L.: Seasonal and diurnal variations of ozone at a high-altitude mountain baseline station in East Asia, Atmos. Environ., 46, 279-288, doi:10.1016/j.atmosenv.2011.09.060, 2012.

Qu, W. J., Arimoto, R., Zhang, X. Y., Zhao, C. H., Wang, Y. Q., Sheng, L. F., and Fu, G.: Spatial distribution and interannual variation of surface $\mathrm{PM}_{10}$ concentrations over eighty-six Chinese cities, Atmos. Chem. Phys., 10, 5641-5662, doi:10.5194/acp-105641-2010, 2010.

Ramanathan, V., Li, F., Ramana, M. V., Praveen, P. S., Kim, D., Corrigan, C. E., Nguyen, H., Stone, E. A., Schauer, J. J., Carmichael, G. R., Adhikary, B., and Yoon, S. C.: Atmospheric brown clouds: Hemispherical and regional variations in long-range transport, absorption, and radiative forcing, J. Geophys. Res.-Atmos., 112, D22S21, doi:10.1029/2006JD008124, 2007.

Randel, W. J., Park, M., Emmons, L., Kinnison, D., Bernath, P., Walker, K. A., Boone, C., and Pumphrey, H.: Asian Monsoon Transport of Pollution to the Stratosphere, Science, 328, 611613, doi:10.1126/science.1182274, 2010.

Randerson, J., van der Werf, G., Giglio, L., Collatz, G., and Kasibhatla, P.: Global Fire Emissions Database, Version 3 (GFEDv3.1), doi:10.3334/ORNLDAAC/1191, 2013.

Riahi, K., Rao, S., Krey, V., Cho, C., Chirkov, V., Fischer, G., Kindermann, G., Nakicenovic, N., and Rafaj, P.: RCP 8.5 - A scenario of comparatively high greenhouse gas emissions, Climatic Change, 109, 33-57, doi:10.1007/s10584-011-0149-y, 2011.

Saikawa, E., Kurokawa, J., Takigawa, M., Borken-Kleefeld, J., Mauzerall, D. L., Horowitz, L. W., and Ohara, T.: The impact of China's vehicle emissions on regional air quality in 2000 and 2020: a scenario analysis, Atmos. Chem. Phys., 11, 9465-9484, doi:10.5194/acp-11-9465-2011, 2011.

Schell, B., Ackermann, I. J., Hass, H., Binkowski, F. S., and Ebel, A.: Modeling the formation of secondary organic aerosol within a comprehensive air quality model system, J. Geophys. Res.Atmos., 106, 28275-28293, 2001.

Seinfeld, J. H. and Pandis, S. N.: Atmospheric chemistry and physics: from air pollution to climate change, John Wiley and Sons, Hoboken, N.J., 2006.

Shaw, W. J., Jerry Allwine, K., Fritz, B. G., Rutz, F. C., Rishel, J. P., and Chapman, E. G.: An evaluation of the wind erosion module in DUSTRAN, Atmos. Environ., 42, 1907-1921, doi:10.1016/j.atmosenv.2007.11.022, 2008.

Stockwell, W. R., Middleton, P., Chang, J. S., and Tang, X.: The second generation regional acid deposition model chemical mechanism for regional air quality modeling, J. Geophys. Res.-Atmos., 95, 16343-16367, doi:10.1029/JD095iD10p16343, 1990.

Stone, E. A., Schauer, J. J., Pradhan, B. B., Dangol, P. M., Habib, G., Venkataraman, C., and Ramanathan, V.: Characterization of emissions from South Asian biofuels and application to source apportionment of carbonaceous aerosol in the Himalayas, J. Geophys. Res.-Atmos., 115, D06301, doi:10.1029/2009JD011881, 2010.

Streets, D. G., Bond, T. C., Carmichael, G. R., Fernandes, S. D., Fu, Q., He, D., Klimont, Z., Nelson, S. M., Tsai, N. Y., Wang, M. Q., Woo, J.-H., and Yarber, K. F.: An inventory of gaseous and primary aerosol emissions in Asia in the year 2000, J. Geophys. Res.-Atmos., 108, 8809, doi:10.1029/2002JD003093, 2003.

Tessum, C. W., Hill, J. D., and Marshall, J. D.: Twelve-month, $12 \mathrm{~km}$ resolution North American WRF-Chem v3.4 air quality simulation: performance evaluation, Geosci. Model Dev., 8, 957973, doi:10.5194/gmd-8-957-2015, 2015.

Tuccella, P., Curci, G., Visconti, G., Bessagnet, B., Menut, L., and Park, R. J.: Modeling of gas and aerosol with WRF/Chem over Europe: Evaluation and sensitivity study, J. Geophys. Res.Atmos., 117, D03303, doi:10.1029/2011JD016302, 2012.

Wang, K., Zhang, Y., Jang, C., Phillips, S., and Wang, B.: Modeling intercontinental air pollution transport over the trans-Pacific region in 2001 using the Community Multiscale Air Quality modeling system, J. Geophys. Res.-Atmos., 114, D04307, doi:10.1029/2008JD010807, 2009.

Wang, X., Liang, X.-Z., Jiang, W., Tao, Z., Wang, J. X. L., Liu, H., Han, Z., Liu, S., Zhang, Y., Grell, G. A., and Peckham, S. E.: WRF-Chem simulation of East Asian air quality: Sensitivity to temporal and vertical emissions distributions, Atmos. Environ., 44, 660-669, doi:10.1016/j.atmosenv.2009.11.011, 2010.

WHO: Ambient Air Pollution Database, available at: http://www.who.int/entity/quantifying_ehimpacts/national/ countryprofile/AAP_PM_database_May2014.xls?ua=1 (last access: 19 November 2014), 2014.

Wild, O., Zhu, X., and Prather, M.: Fast-J: Accurate Simulation of In- and Below-Cloud Photolysis in Tropospheric Chemical Models, J. Atmos. Chem., 37, 245-282, doi:10.1023/A:1006415919030, 2000.

Yamaji, K., Ohara, T., Uno, I., Tanimoto, H., Kurokawa, J.I., and Akimoto, H.: Analysis of the seasonal variation of ozone in the boundary layer in East Asia using the Community Multi-scale Air Quality model: What controls surface 
ozone levels over Japan?, Atmos. Environ., 40, 1856-1868, doi:10.1016/j.atmosenv.2005.10.067, 2006.

Yegorova, E. A., Allen, D. J., Loughner, C. P., Pickering, K. E., and Dickerson, R. R.: Characterization of an eastern U.S. severe air pollution episode using WRF/Chem, J. Geophys. Res.-Atmos., 116, doi:10.1029/2010JD015054, 2011.

Zhang, B., Wang, Y., and Hao, J.: Simulating aerosol-radiationcloud feedbacks on meteorology and air quality over eastern China under severe haze conditionsin winter, Atmos. Chem. Phys., 15, 2387-2404, doi:10.5194/acp-15-2387-2015, 2015.

Zhang, X., van Geffen, J., Liao, H., Zhang, P., and Lou, S.: Spatiotemporal variations of tropospheric $\mathrm{SO}_{2}$ over China by SCIAMACHY observations during 2004-2009, Atmos. Environ., 60, 238-246, doi:10.1016/j.atmosenv.2012.06.009, 2012.
Zhang, X. Y., Arimoto, R., Cao, J. J., An, Z. S., and Wang, D.: Atmospheric dust aerosol over the Tibetan Plateau, J. Geophys. Res.-Atmos., 106, 18471-18476, doi:10.1029/2000JD900672, 2001.

Zhao, C., Wang, Y., Yang, Q., Fu, R., Cunnold, D., and Choi, Y.: Impact of East Asian summer monsoon on the air quality over China: View from space, J. Geophys. Res.-Atmos., 115, D09301, doi:10.1029/2009JD012745, 2010. 